ISSN 1420-3049

www.mdpi.com/journal/molecules

Article

\title{
Synthesis of Thiophene and NO-Curcuminoids for Antiinflammatory and Anti-Cancer Activities
}

\author{
Mahera M. Ahmed, M. Akram Khan * and Kim Drummond Rainsford \\ Biomedical Research Centre, Sheffield Hallam University, Howard Street, Sheffield S11WB, UK \\ * Author to whom correspondence should be addressed; E-Mail: m.a.khan@shu.ac.uk; \\ Tel.: +44-0-1142254451; Fax: +44-0-1142253066.
}

Received: 13 November 2012; in revised form: 7 January 2013 / Accepted: 15 January 2013 /

Published: 25 January 2013

\begin{abstract}
In search of better NSAIDs four novel nitric oxide donating derivatives of curcumin (compounds 9a-d), and four thiophene curcuminoids (compounds 10a-c, 11) have been synthesised. The cytotoxic effects of these compounds along with the lead compound curcumin (7) and their effect on the production of the reactive oxygen species nitric oxide and pro-inflammatory cytokines IL- $1 \beta$, TNF- $\alpha$ and chemokine CXCL- 8 were evaluated using human monocytic THP-1 and colon adenocarcinoma CACO-2 cell lines. All of the nitric oxide donating curcuminoids $9 \mathbf{a}-\mathbf{d}$ and the thiophene curcuminoids $10 \mathbf{a}-\mathbf{c}$ and 11 were non-cytotoxic to THP-1 cells over a concentration range of 10-100 $\mu \mathrm{M}$ and compared with curcumin compounds $\mathbf{1 0 b}$ and $\mathbf{1 0 c}$, were more toxic. In CACO-2 cells, 10b and 11 appeared to be non-toxic at 10 to $50 \mu \mathrm{M}$, whereas $10 \mathrm{a}$ and 10c were non-cytotoxic at $10 \mu \mathrm{M}$ only. These results clearly indicate that the introduction of a nitroxybutyl moiety to curcumin and replacement of phenyl rings with thiophene units reduces the cytotoxic effect of the parent curcumin, whereas a methyl substituted thiophene increases the cytotoxic effects. In THP-1 cells, drugs 10a and 11 significantly decreased IL-1- $\beta$ production at their non-cytotoxic concentrations, whereas, they did not decrease TNF- $\alpha$ production in CACO-2 cells. Compound 11 showed a significant decrease in CXCL-8 production.
\end{abstract}

Keywords: NO-NSAIDs; synthesis; curcuminoids; cytotoxicity; cytokines; chemokines; anti-cancer 


\section{Introduction}

In the last two decades curcumin and its derivatives have received widespread interest for their therapeutic effects for various indications [1] for example, in treating inflammatory conditions and cancer [1-7]. We recently reported the anti-inflammatory activities, determined in vivo and in vitro, for a range of novel aromatic and heterocyclic aromatic curcuminoids [8]. Some of our novel curcuminoids may form the basis for development of new low gastro-toxicity anti-inflammatory agents with selective activity as inhibitors of cytokine inflammatory mediators.

Here we report the anti-inflammatory properties of some nitric oxide donating curcuminoids 9a-d analogous to the nitric oxide donating non-steroidal anti-inflammatory drugs NO-NSAIDs. Nitrate esters such as cellulose nitrate and glycerol nitrate are esters of nitric acid that have been known for over 150 years. However, recently the synthesis of nitrate esters and in particular 4-nitroxy-1-butylcarboxylates has received a renewed interest as antiinflammatory agents [9-14]. The development of NO-NSAIDs is based on various findings whereby NO compliments some of the properties of the prostaglandins (PGs) within the gastric mucosa, thus the NO-coupled NSAIDs might deliver NO to the site where NSAIDs induce micosal damage, thereby decreasing the gastric toxicity, which is often a consequence of diminished PG levels in the gastric mucosa [15]. NO-aspirin and other NSAIDs 1-4 with NO donating activity have been reported to suppress platelet aggregation and thereby inflammation with much reduced gastrointestinal tract injury. These NO-NSAIDs (Figure 1) are reported as stable in aqueous solutions and well absorbed after oral administration [15]. Though a number of studies have shown NO-NSAIDs to have enhanced anti-inflammatory activity with lesser side-effects, their major limitation is the rapid release of NO with relatively small quantities being produced in the systemic circulation [16-18]. The NO donating curcuminoids 6-9 were developed seeking potentially prolonged production of $\mathrm{NO}$ in vivo.

Figure 1. NO-NSAIDs reported in the literature.
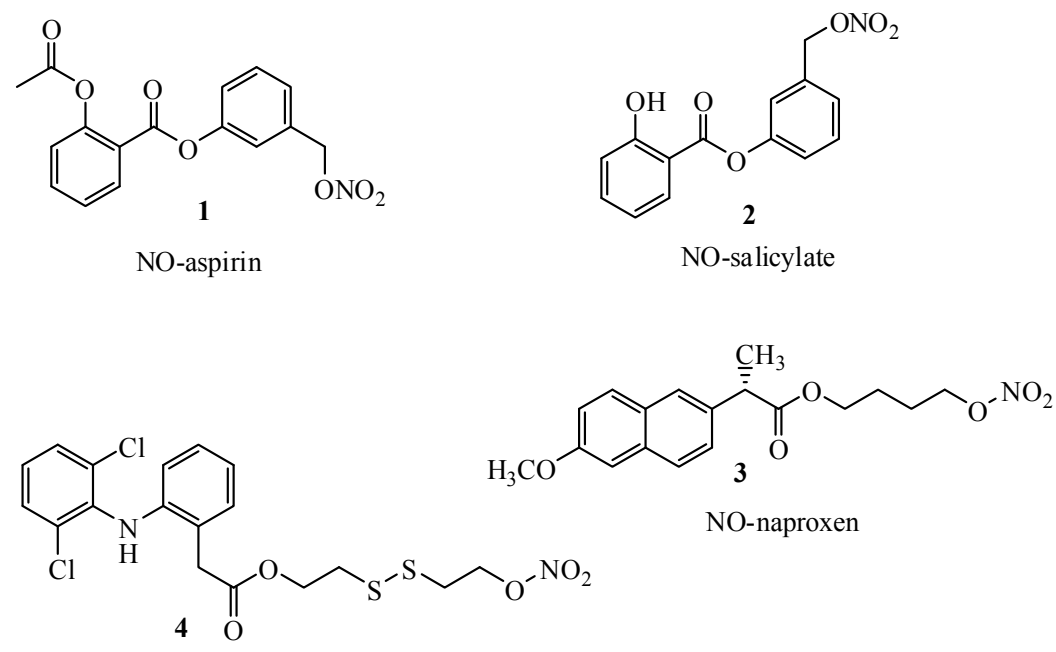

NO-diclofenac

Here we report the synthesis of NO-curcuminoids $\mathbf{9 a - d}$, all containing the 4-nitroxybut-1-yl group as a nitric oxide donating group. Their cytotoxicity and potential anti-inflammatory and anti-cancer activities are reported in terms of effects on NO, the cytokines IL-1, TNF- $\alpha$ and chemokine CXCL-8 
(IL-8) production relative to the naturally occurring curcumin (7). Some novel thiophenyl curcuminoids 10a-c, 11 [8] (Figure 2) were also investigated in human monocytic THP-1 and adenocarcinoma-derived CACO-2 cell lines. The effects on the cytokines were studied as chemokine CXCL-8 has similarly been reported to be involved in the pathogenesis of a number of disorders including inflammatory bowel diseases [19-21]. The cytotoxic effects of thiophene derivatives 10a-c, 11 complexed with HP- $\gamma$-CD were also assessed using the THP-1 cells. IL-1 $\beta$ and TNF- $\alpha$, initiates a cascade of events leading to inflammation and tissue destruction in various inflammatory diseases [22-24].

Figure 2. Synthesised thiophene and NO-curcuminoids.<smiles>COc1cc(/C=C/C(=O)CC(=O)/C=C/c2ccc(O)c(OC)c2)ccc1O</smiles><smiles>O=C(/C=C/c1ccccc1OCCCCO[Na])CC(=O)/C=C/c1ccccc1OCCCCO[N+](=O)[O-]</smiles><smiles>O=C(/C=C/c1cccc(OCCCCO[N+](=O)[O-])c1)CC(=O)/C=C/c1cccc(OCCCCO[O+]([O-])O[Na])c1</smiles><smiles>O=C(/C=C/c1ccc(OCCCCO[N+](=O)[O-])cc1)CC(=O)/C=C/c1ccc(OCCCCO[O+]([O-])O[O-])cc1</smiles><smiles>COc1cc(/C=C/C(=O)CC(=O)/C=C/c2ccc(OCCCCO[N+](=O)[O-])c(OC)c2)ccc1OCCCCO[N+](=O)[O-]</smiles><smiles>[R]c1sc(/C=C/C(=O)CC(=O)/C=C/c2sc([R])c([R])c2[R3])c([R3])c1[R]</smiles><smiles>O=C(/C=C/c1ccsc1)CC(=O)/C=C/c1ccsc1</smiles>
a. $\mathrm{R}_{1}=\mathrm{R}_{2}=\mathrm{R}_{3}=\mathrm{H}$
b. $\mathrm{R}_{1}=\mathrm{R}_{2}=\mathrm{H}, \mathrm{R}_{3}=\mathrm{CH}_{3}$
c. $\mathrm{R}_{1}=\mathrm{CH}_{3}, \mathrm{R}_{2}=\mathrm{R}_{3}=\mathrm{H}$ 


\section{Results and Discussion}

\subsection{Chemistry}

The NO-curcuminoids were synthesized in three steps as shown in Scheme 1. The synthesis of curcuminoids from the aldehydes $\mathbf{5 a}-\mathbf{d}$ followed by alkylation with excess dibromobutane to produce the 4-bromobutoxy curcuminoids failed, and the best method for making the target compounds 9a-d was that shown in Scheme 1. It is important to note that the synthesised NO-curcuminoids 9a-d are phenolic ethers of NO as compared with the carboxylate esters of conventional NO-NSAIDs reported in the literature and shown in Figure 1. We have recently reported that 2-methoxycurcuminoid has higher anti-cancer activity compared with other derivatives [25] and in this study we have made a systematic attempt to examine the activity profile of butoxynitrate group in positions 2, 3 and 4 of the aromatic ring in curcuminoids $\mathbf{9 a}-\mathbf{d}$.

Scheme 1. Synthesis of NO-curcuminoids $\mathbf{9 a}-\mathbf{d}$.

Step 1 : Synthesis of bromobutoxyaldehydes $\mathbf{6 a}-\mathbf{d}$<smiles>[R]c1ccc(C=O)c([R])c1[R]</smiles>

5 (i) $\mathrm{NaOEt} / \mathrm{EtOH}$

(ii) $\mathrm{Br} \sim \mathrm{Br}$ reflux, $12 \mathrm{hr}$<smiles>[R]c1ccc(C=O)c([R])c1[R]</smiles>

6
a : $\mathrm{R}_{1}=(-\mathrm{OH}), \mathrm{R}_{2}=\mathrm{R}_{3}=(-\mathrm{H})$
b : $\mathrm{R}_{1}=\mathrm{R}_{3}=(-\mathrm{H}), \mathrm{R}_{2}=(-\mathrm{OH})$
c : $\mathrm{R}_{1}=\mathrm{R}_{2}=(-\mathrm{H}), \mathrm{R}_{3}=(-\mathrm{OH})$
d : $\mathrm{R}_{1}=(-\mathrm{H}), \mathrm{R}_{2}=\left(-\mathrm{OCH}_{3}\right), \mathrm{R}_{3}=(-\mathrm{OH})$

$$
\begin{aligned}
& \text { a : } \mathrm{R}_{1}=\left(-\mathrm{O}-\left(\mathrm{CH}_{2}\right)_{4}-\mathrm{Br}\right), \mathrm{R}_{2}=\mathrm{R}_{3}=(-\mathrm{H}) \\
& \text { b : } \mathrm{R}_{1}=\mathrm{R}_{3}=(-\mathrm{H}), \mathrm{R}_{2}=\left(-\mathrm{O}-\left(\mathrm{CH}_{2}\right)_{4}-\mathrm{Br}\right) \\
& \text { c }: \mathrm{R}_{1}=\mathrm{R}_{2}=(-\mathrm{H}), \mathrm{R}_{3}=\left(-\mathrm{O}-\left(\mathrm{CH}_{2}\right)_{4}-\mathrm{Br}\right) \\
& \text { d : } \mathrm{R}_{1}=(-\mathrm{H}), \mathrm{R}_{2}=\left(-\mathrm{OCH}_{3}\right), \mathrm{R}_{3}=\left(-\mathrm{O}-\left(\mathrm{CH}_{2}\right)_{4}-\mathrm{Br}\right)
\end{aligned}
$$

Step 2 : Synthesis of curcumin 7 and bromobutoxy curcuminoids $8 \mathbf{a}-\mathbf{d}$

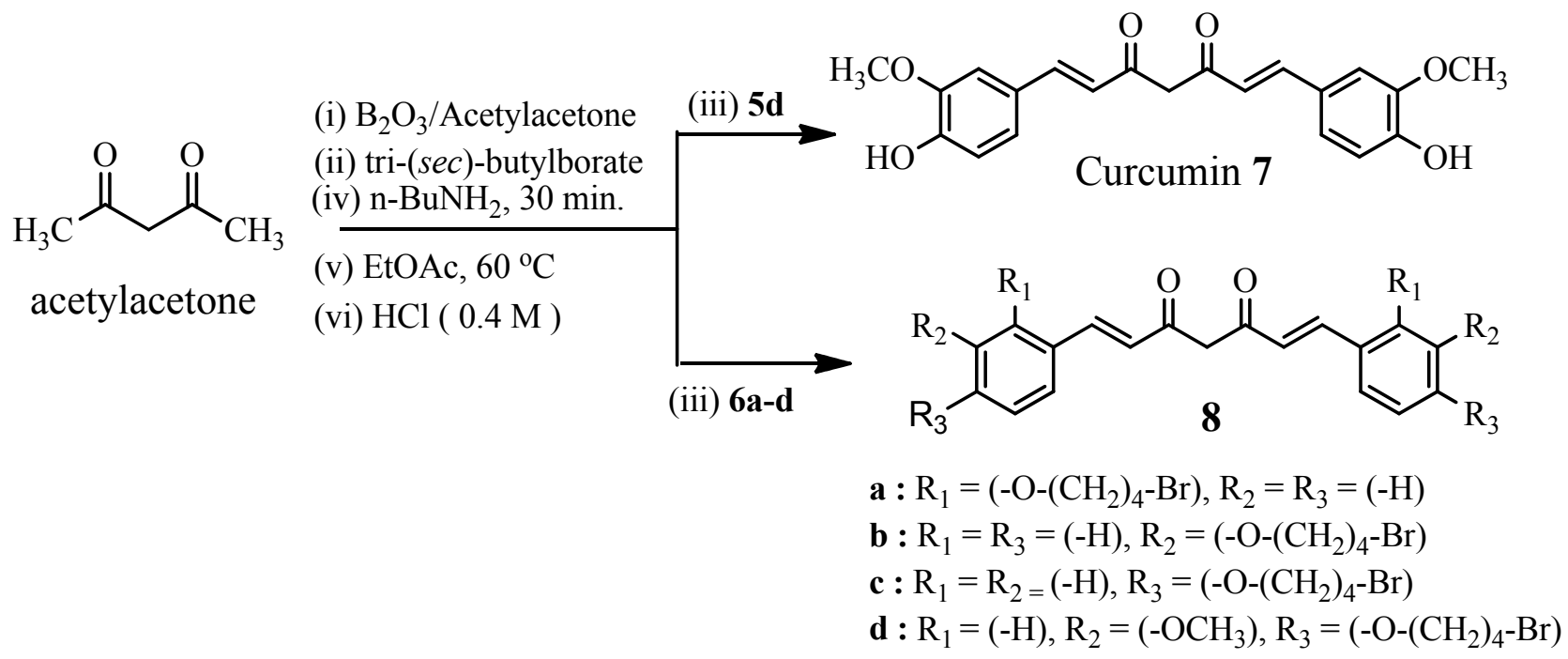


Scheme 1. Cont.

Step 3 : Synthesis of butoxynitrate curcuminoids 9a- d<smiles>[R3]c1ccc(/C=C/C(=O)CC(=O)/C=C/c2ccc([R3])c([R])c2[R])c([Y9])c1[R16]</smiles>

$\mathbf{a}: \mathrm{R}_{1}=\left(-\mathrm{O}-\left(\mathrm{CH}_{2}\right)_{4}-\mathrm{Br}\right), \mathrm{R}_{2}=\mathrm{R}_{3}=(-\mathrm{H})$

b : $\mathrm{R}_{1}=\mathrm{R}_{3}=(-\mathrm{H}), \mathrm{R}_{2}=\left(-\mathrm{O}-\left(\mathrm{CH}_{2}\right)_{4}-\mathrm{Br}\right)$

c : $\mathrm{R}_{1}=\mathrm{R}_{2}=(-\mathrm{H}), \mathrm{R}_{3}=\left(-\mathrm{O}-\left(\mathrm{CH}_{2}\right)_{4}-\mathrm{Br}\right)$

d : $\mathrm{R}_{1}=(-\mathrm{H}), \mathrm{R}_{2}=\left(-\mathrm{OCH}_{3}\right), \mathrm{R}_{3}=\left(-\mathrm{O}-\left(\mathrm{CH}_{2}\right)_{4}-\mathrm{Br}\right)$<smiles>[R]c1ccc(/C=C/C(=O)CC(=O)/C=C/c2ccc([R3])c([R])c2[R])c([R])c1[R]</smiles>

$\mathbf{a}: \mathrm{R}_{1}=\left(-\mathrm{O}-\left(\mathrm{CH}_{2}\right)_{4}-\mathrm{ONO}_{2}\right), \mathrm{R}_{2}=\mathrm{R}_{3}=(-\mathrm{H})$

$\mathbf{b}: \mathrm{R}_{1}=\mathrm{R}_{3}=(-\mathrm{H}), \mathrm{R}_{2}=\left(-\mathrm{O}-\left(\mathrm{CH}_{2}\right)_{4}-\mathrm{ONO}_{2}\right)$

c : $\mathrm{R}_{1}=\mathrm{R}_{2}=(-\mathrm{H}), \mathrm{R}_{3}=\left(-\mathrm{O}-\left(\mathrm{CH}_{2}\right)_{4}-\mathrm{ONO}_{2}\right)$

d : $\mathrm{R}_{1}=(-\mathrm{H}), \mathrm{R}_{2}=\left(-\mathrm{OCH}_{3}\right), \mathrm{R}_{3}=\left(-\mathrm{O}-\left(\mathrm{CH}_{2}\right)_{4}-\right.$ $\mathrm{ONO}_{2}$ )

All the synthesized compounds (Figure 2 and Scheme 1) were purified by flash column chromatograpy and characterized spectroscopically. Thiophene and furan curcuminoids possess potent anti-inflammatory properties [8], and the pharmacological activities of these curcuminoids was compared with our NO-curcuminoids $9 \mathbf{a}-\mathbf{d}$ and the natural curcumin (7).

\subsection{Pharmacology}

Curcumin (7), its nitric oxide donating derivatives 9a-d and thiophene derivatives 10a-d, 11 were evaluated for cytotoxicity, production of NO and pro-inflammatory cytokines (IL-1 $\beta$, TNF- $\alpha$ and chemokine CXCL-8) using the human monocytic leukamia, THP-1 and the human Caucasian colon adenocarcinoma-2, CACO-2 cell lines. For stimulating the cells we used the two activating agents LPS and L-methionine sulfoximine (MS). LPS acts by binding to receptors on cell membranes whilst MS acts as a membrane active agent that opens up cell membranes to release enzymes. Our aim was to compare the effects of the active compounds with the parent compound, curcumin (7), and to determine the structure-activity relationships of the active compounds as a guide to design future derivatives of curcumin with enhanced biological potency.

\subsubsection{Cytotoxicity}

At $10 \mu \mathrm{M}$, all compounds were as non-toxic, as was curcumin (7), to THP-1 cells. However, at concentrations of 50 and $100 \mu \mathrm{M}$, the NO donating compounds $\mathbf{1 0 a}-\mathbf{c}$ and 11 were significantly less toxic than curcumin (7) (Figure 3).

From the structure-activity relationships, it appears that the replacement of both the phenolic hydrogens of curcumin (7) with the nitroxybutyl ether moiety enhances the non-cytotoxic properties of these compounds. However, the presence of the methoxy group $\left(-\mathrm{OCH}_{3}\right)$ at the meta positions of the phenyl rings, as is found in compounds 7 and 9d, does not seem to be crucial for the cytotoxic effects since compounds $\mathbf{9 a}-\mathbf{c}$ do not possess any $-\mathrm{OCH}_{3}$ groups and these were as non-cytotoxic as $\mathbf{9 d}$ at 50 and $100 \mu \mathrm{M}$ (Figure 3). Furthermore, change in the position of the nitroxybutyl moiety in structures of the compounds $9 \mathbf{a}-\mathbf{c}$ also did not have any effect on cell viability. Thus, it appears that all of the 
nitroxybutyl curcuminoids $\mathbf{9 a}-\mathbf{d}$ are non-toxic to THP-1 cells and are less cytotoxic than curcumin (7) at 10,50 and $100 \mu \mathrm{M}$ concentrations.

Figure 3. The effects of curcumin (7) and nitric oxide donating curcuminoids $9 a-\mathbf{d}$ on the viability of THP-1 cells as determined by the MTS assay. Results are presented as mean \pm SD. $* p<0.05$ compared with DMSO control, * $p>0.05$ compared with curcumin control (7).

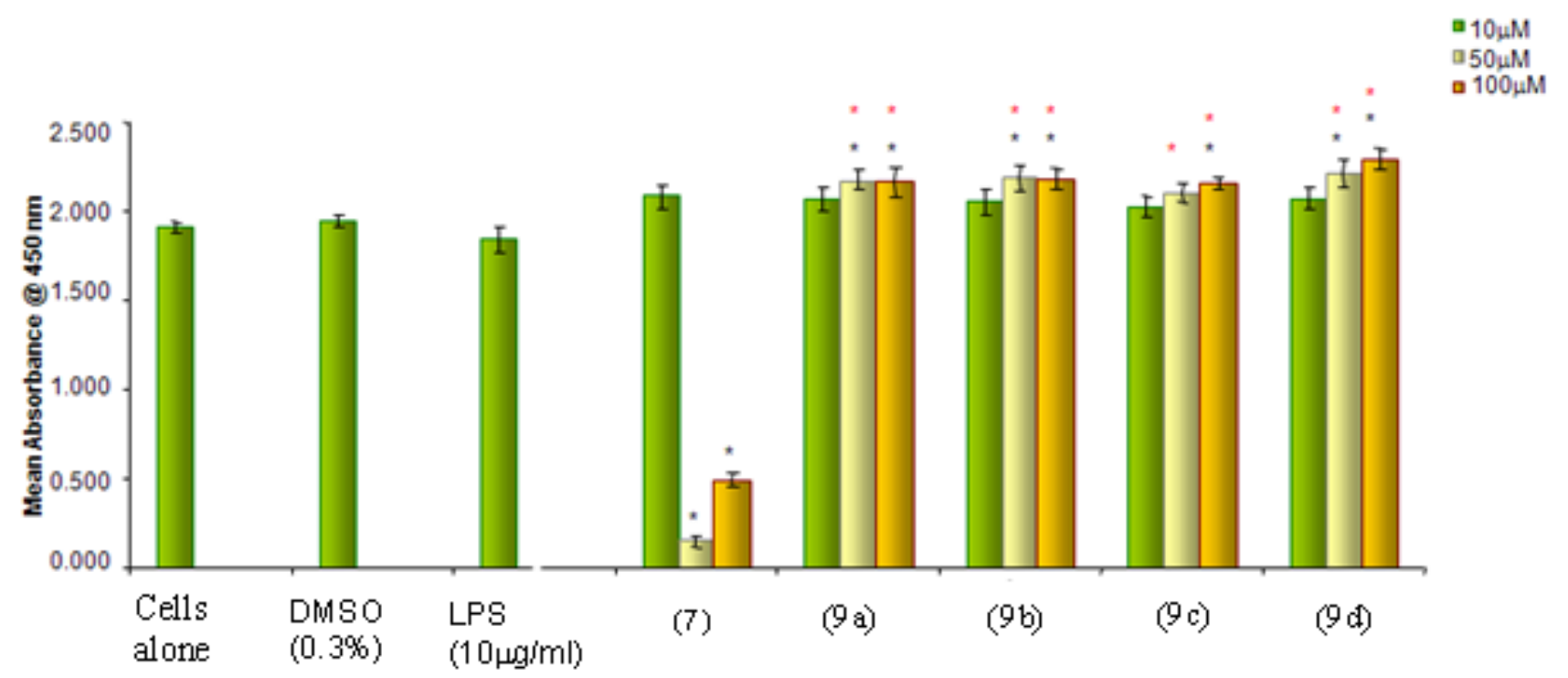

The replacement of both of the phenyl rings of the curcumin (7) with thiophene rings resulted in lesser cytotoxic effects on THP-1 cells. Amongst all four thiophene curcuminoids, compounds $\mathbf{1 0 b}$ and 10c which are the methyl substituted derivatives of 10a at the 3 and 5 positions, respectively, show significant $(p<0.05)$ cytotoxic effects in concentration-dependent manner, suggesting the methyl group as being responsible for the cytotoxic effects (Figure 4). On the other hand compound 11 which is a positional isomer of $\mathbf{1 0 a}$ also appeared to be less cytotoxic than $\mathbf{1 0 b}$ and $\mathbf{1 0 c}$, which further confirms that there is a possibility of a methyl group being involved in the induction of cytotoxic effects associated with these derivatives. In comparison with the curcumin (7) the thiophene curcuminoids 10a and $\mathbf{1 1}$ at $10 \mu \mathrm{M}$, have similar cytotoxicity to curcumin 7 whereas the methyl substituted curcuminoids $\mathbf{1 0 b}$ and 10c appeared to be more cytotoxic than curcumin (7). Since 10b and 10c at their lowest concentration $(10 \mu \mathrm{M})$ are more toxic than curcumin (7), these could serve as potential anti-cancer drugs (Figure 4). In CACO-2 cells all the compounds 10a-c, 11 had a similar toxicity profile as curcumin (7) but at $50 \mu \mathrm{M}$ concentration only the 5-methyl derivative 10c showed increased cytotoxicity that was similar to that of curcumin (7). The toxicity profile of the 5-methylthiophene derivative 10c appears to be very similar in both THP-1 and CACO-2 cells (Figure 5). 
Figure 4. The effects of curcumin (7) and thiophene curcuminoids 10a-c, 11 on the viability of THP-1 cells as determined by the MTS assay. Results are presented as mean \pm SD. $* p<0.05$ compared with DMSO control, * $p>0.05$ compared with curcumin control (7).

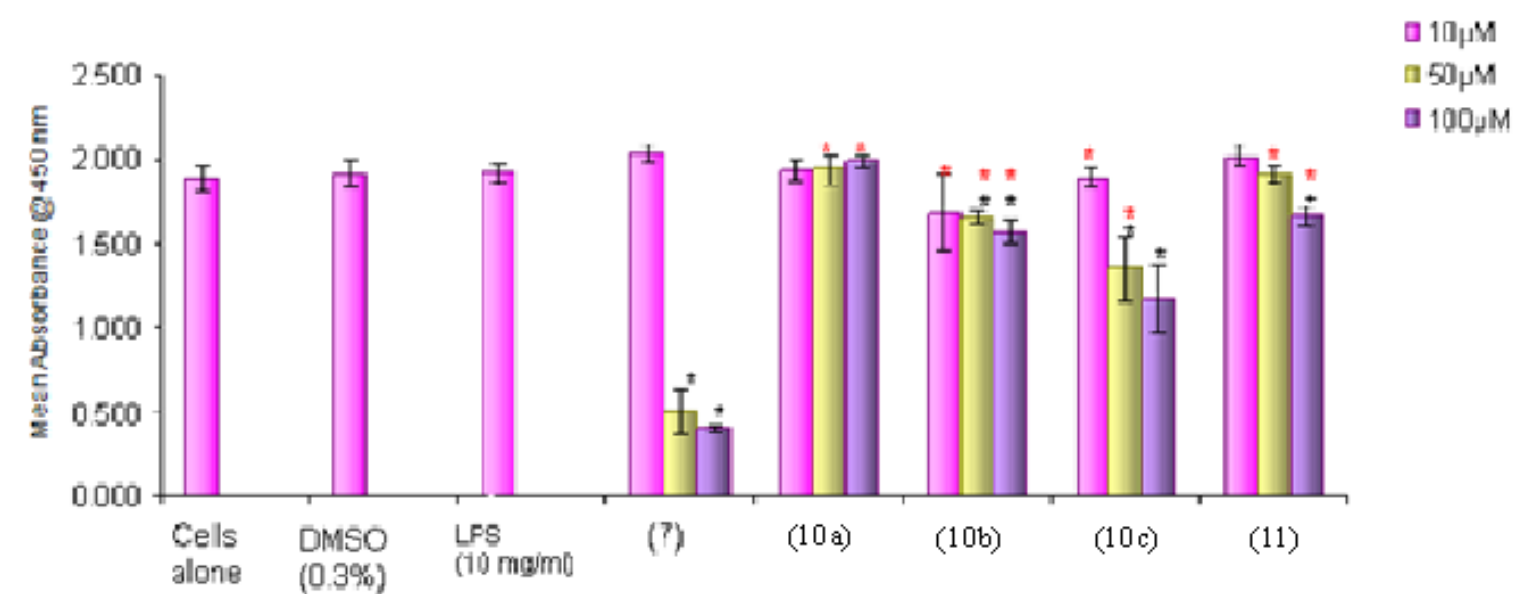

Figure 5. The effects of curcumin (7) and thiophene curcuminoids 10a-c, 11 on the viability of CACO-2 cells as determined by the MTS assay. Results are presented as mean \pm SD. $* p<0.05$ compared with DMSO control, $* p>0.05$ compared with curcumin control (7).

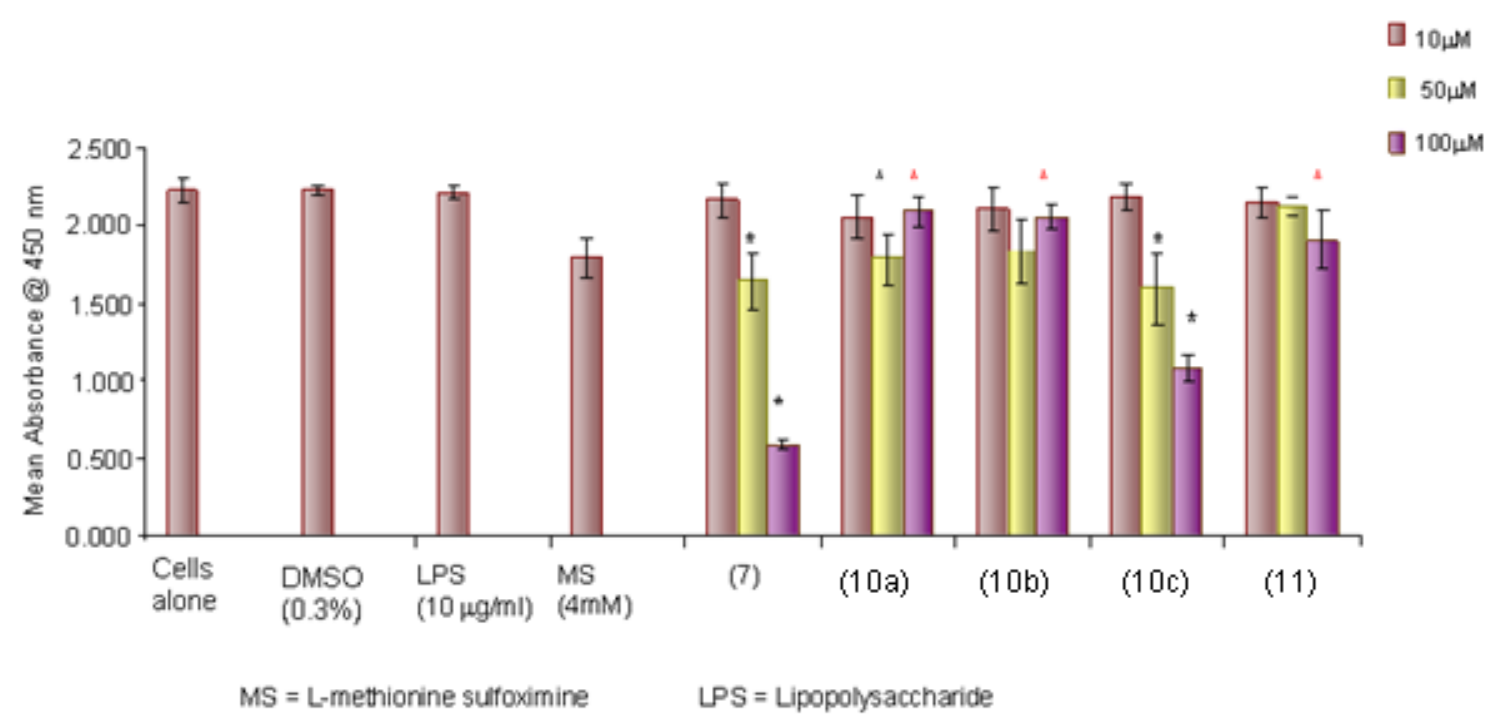

\subsubsection{Nitric Oxide Production}

In THP-1 cells all NO-derivatives of curcumin enhanced the production of NO in a concentrationdependent manner, except for 9c (Figures 6 and 7). From the structure activity relationships it appears that the replacement of the phenolic hydrogen of curcumin (7) with the nitroxybutyl ether moiety significantly enhances nitric oxide production. Compared to the DMSO control a concentration dependent increase in the production of nitrite was observed with compounds $9 \mathbf{a}, \mathbf{9 b}$ and $9 \mathbf{d}$ at all the three concentrations but the effect was significant at 50 and $100 \mu \mathrm{M}$. In comparison to the cells alone control, DMSO + LPS control significantly reduced the nitrite production, whereas the LPS control caused a non-significant effect in nitrite production (Figure 7). Compared with curcumin (7) at $10 \mu \mathrm{M}$ concentration a significant increase in nitrite production was observed in THP-1 cells that were 
stimulated with LPS for compound 9b. Compounds 9a, 9b and 9d significantly increased the nitrite production at 50 and $100 \mu \mathrm{M}$, whereas curcumin was cytotoxic at these concentrations (Figure 7). When compared with the DMSO + LPS control a concentration dependent increase in nitrite production was observed with 9a whilst with $9 \mathbf{b}$ the effect was equally significant at all the three concentrations studied.

Figure 6. The effects of synthesized curcumin (7) and nitric oxide donating curcuminoids 9a-d on the production of nitric oxide in THP-1 cells using the Griess reagent. Results are presented as mean $\pm \mathrm{SD}$. ${ }^{*} p<0.05$ compared with DMSO control, $* p>0.05$ compared with curcumin control (7).

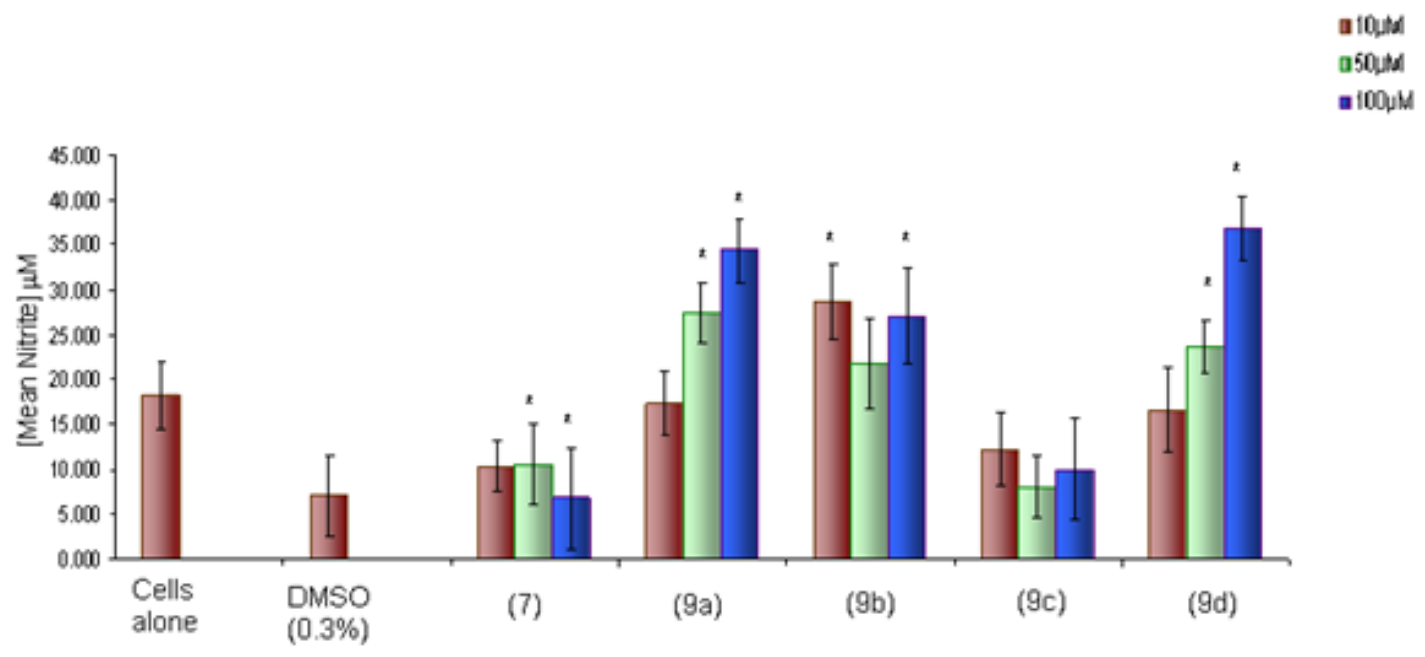

Figure 7. The effects of synthesized curcumin (7) and nitric oxide donating curcuminoids 9a-d on the production of nitric oxide in LPS-induced THP-1 cells using the Griess reagent. Results are presented as mean $\pm \mathrm{SD}$. ${ }^{*} p<0.05$ compared with DMSO + LPS control, $* p>0.05$ compared with curcumin control (7).

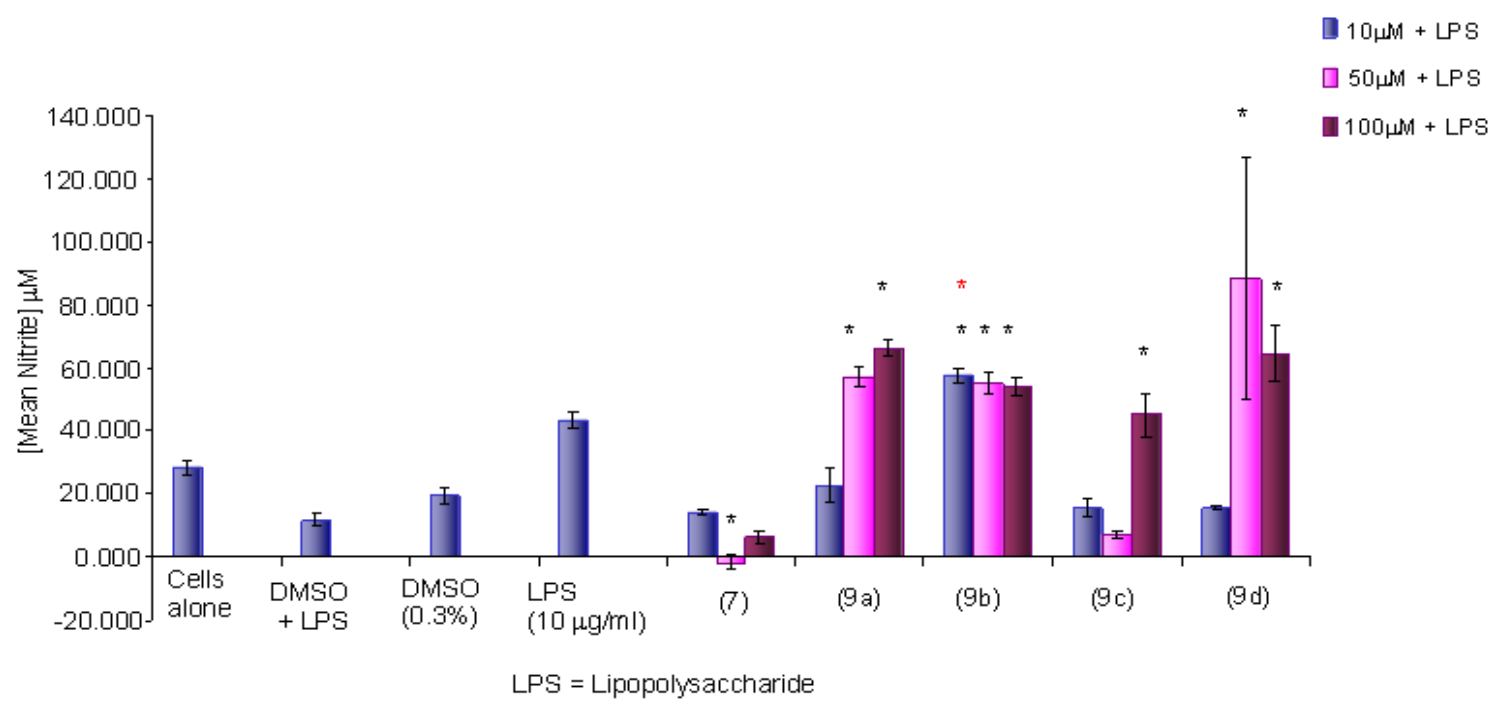




\subsubsection{Cytokine Production}

The results show that curcumin (7) at $10 \mu \mathrm{M}, \mathbf{1 0 a}$ and 11 significantly decreased IL-1 $\beta$ production in a concentration-dependent manner in THP-1 cells stimulated with LPS. In the case of compounds 10b and 10c the decreased effect in IL- $1 \beta$ production exhibited at $10 \mu \mathrm{M}$ was also significant and this may be attributed to cytotoxicity. In comparison, all compounds were as potent as curcumin (7) at $10 \mu \mathrm{M}$. The thiophene curcuminoids $\mathbf{1 0 a}$ from 10 to $100 \mu \mathrm{M}$ and $\mathbf{1 1}$ at 10 to $50 \mu \mathrm{M}$ range may be potential future anti-inflammatory drugs as they inhibit IL-1 $\beta$ production in THP-1 leukaemia cells and have low cytotoxicity (Figure 8).

Figure 8. The effects of curcumin (7) and thiophene curcuminoids 10a-c, 11 on the production of IL-1 in LPS-induced THP-1 cells using ELISA assay. Results are presented as mean \pm SD. $* p<0.05$ compared with DMSO + LPS control, $* p>0.05$ compared with curcumin control (7).

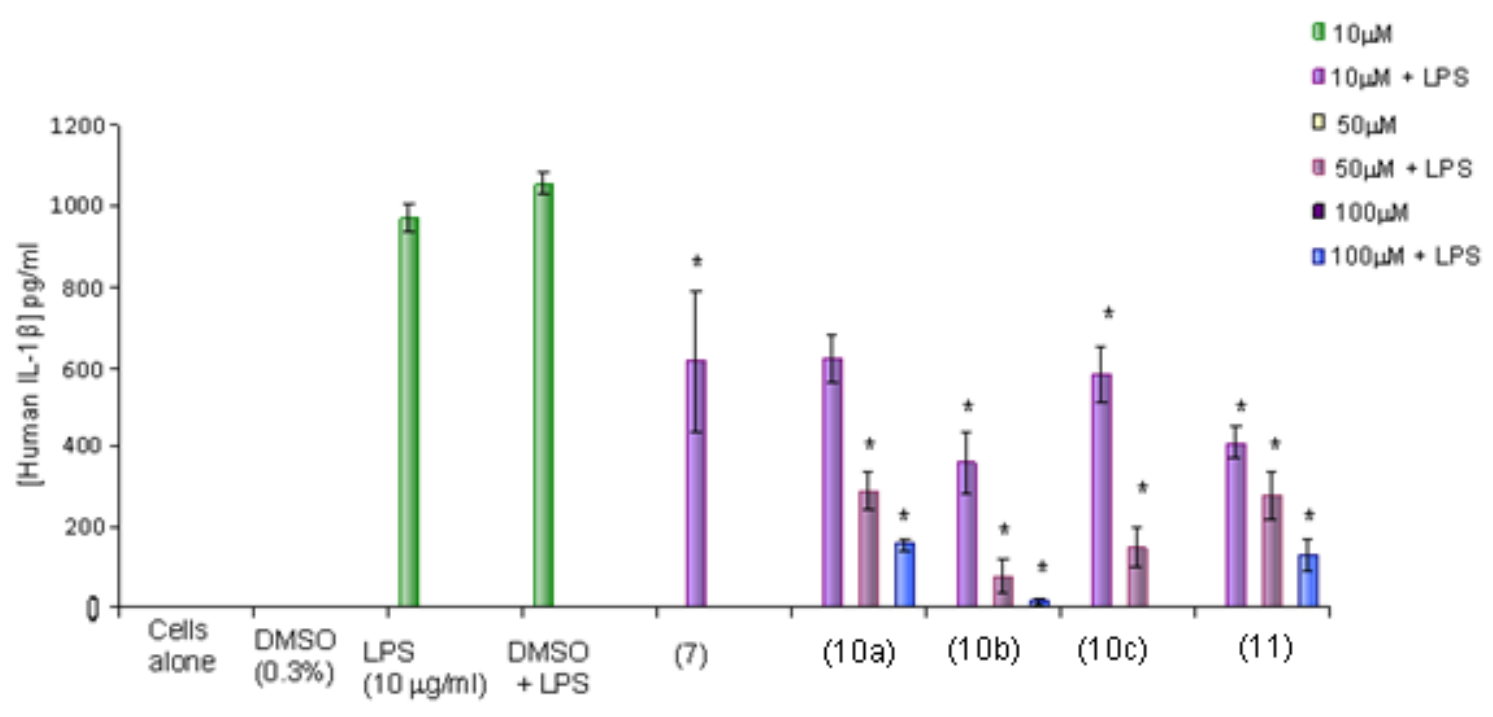

Curcumin (7) inhibits the production of pro-inflammatory cytokines LPS-induced IL-1, IL-6 and TNF- $\alpha$ in THP-1 cells [20]. None of the thiophene curcuminoids $\mathbf{1 0 a}-\mathbf{c}, \mathbf{1 1}$ or curcumin (7) alone affected production of TNF- $\alpha$ at all the three concentration 10, 50 and $100 \mu \mathrm{M}$. However, treatment of LPS stimulated cells with curcumin (7) for $24 \mathrm{~h}$ resulted in a concentration-dependent decrease in TNF- $\alpha$ production albeit the effects being significant only at 50 and $100 \mu \mathrm{M}$. This inhibitory effect might be due to cytotoxic effects (Figure 9). Furthermore, none of the thiophene curcuminoids 10a-c, 11 at their non-cytotoxic concentrations inhibited TNF- $\alpha$ production in LPS stimulated cells. Curcumin (7) and all its synthesised thiophene derivatives 10a-d, 11 appeared to be non-cytotoxic at $10 \mu \mathrm{M}$ concentration (Figure 9). 
Figure 9. The effects of synthesized curcumin (7) and thiophene curcuminoids 10a-c, 11 on the production of TNF- $\alpha$ in LPS-induced THP-1 cells using ELISA assay. Results are presented as mean $\pm \mathrm{SD}$. $* p<0.05$ compared with DMSO + LPS control, $* p>0.05$ compared with curcumin control (7).

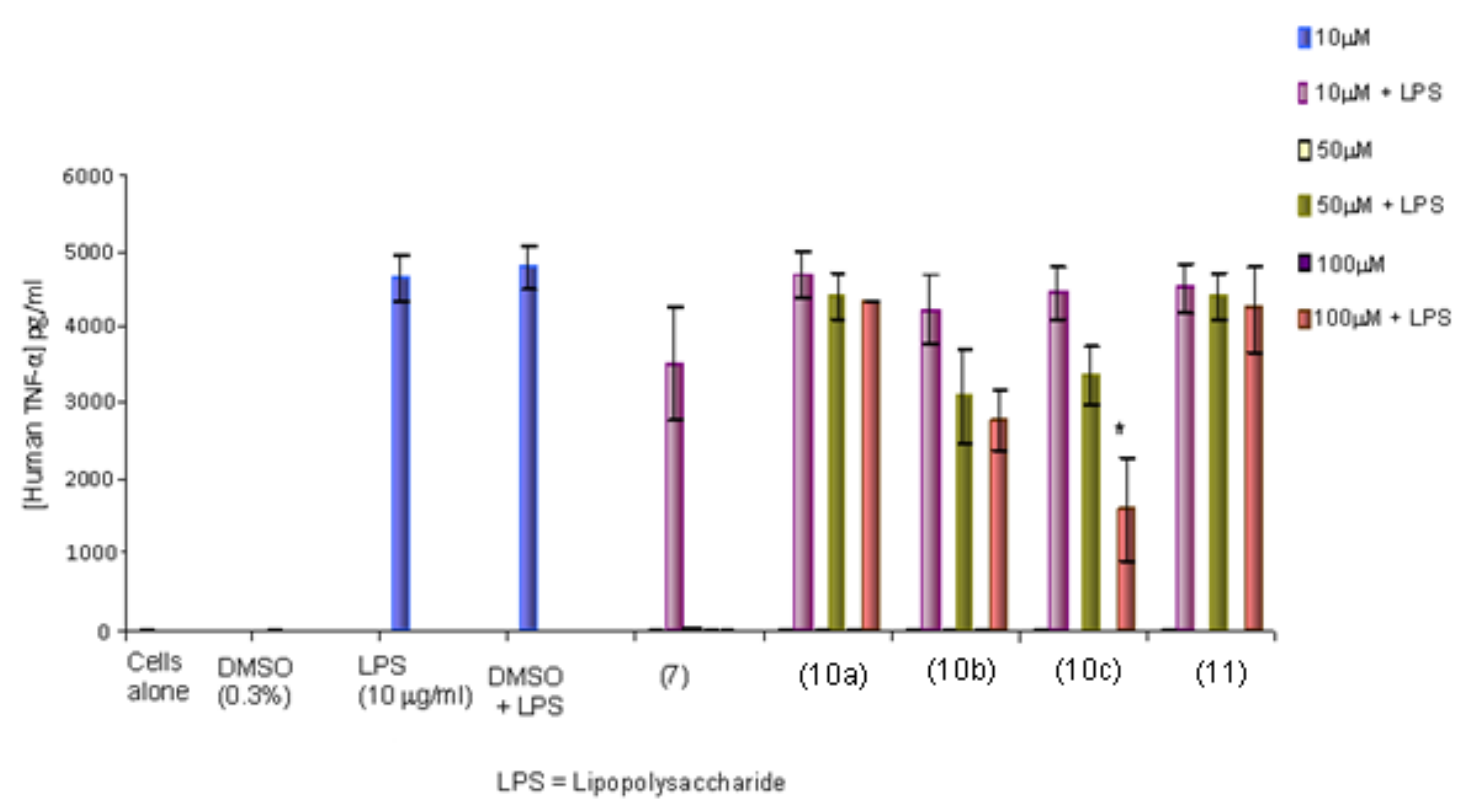

\subsubsection{Chemokine Production}

Curcumin (7) did not affect the LPS-induced production of the CXCL-8 chemokine compared with the solvent control (Figure 10). However, the thiophene compounds 10a-c and $\mathbf{1 1}$ reduced the LPS-induced production of CXCL-8 chemokine in a concentration-dependent manner compared with the DMSO solvent control. Thus at $10 \mu \mathrm{M}$, compounds $10 \mathrm{~b}$ and $10 \mathrm{c}$ significantly reduced the production of CXCL-8 whereas 10a and 11, like curcumin (7), did not affect the production of CXCL-8. At $50 \mu \mathrm{M}$ all the compounds significantly reduced the CXCL-8 production except 10c. At the highest concentration of $100 \mu \mathrm{M}$, a significant decrease in CXCL-8 production was observed with all the compounds. A significant increase in the production of CXCL-8 was observed when the cells were treated with MS in the presence of LPS and DMSO. In comparison, the combined treatments with the (DMSO + LPS + MS) control, curcumin (7), as well as compounds 10a and 10b were effective inhibitors.

\subsubsection{Discussion of Pharmacology and Conclusions}

The cytotoxicity studies showed that all of the nitroxybutyl curcuminoids $\mathbf{9 a}-\mathbf{d}$ and thiophene curcuminoid 10a appeared in general to be non or less toxic to THP-1 cells than curcumin (7). Thus, addition of the nitrobutoxy moiety has the effect of reducing cytotoxicity of curcumin. These nitroxybutyl curcuminoids $9 \mathbf{9}-\mathbf{d}$ all produce nitric oxide, but this was not evident with curcumin (7). High concentrations of some of the nitroxybutyl curcuminoids variously reduces production of IL- $1 \beta$ and TNF $\alpha$ and in the case of thiophene compounds reduces production of the CXCL-8 chemokine. The thiophene compounds $\mathbf{1 0 a}-\mathbf{c}, \mathbf{1 1}$ and some of the nitroxybutyl curcuminoinds $\mathbf{9 a}-\mathbf{d}$ may have potential in the future as anti-inflammatory agents. 
Figure 10. The effects of curcumin (7) and thiophene curcuminoids 10a-c, 11 on the production of CXCL-8 in MS and LPS-induced CACO-2 cells using ELISA assay. Results are presented as mean $\pm \mathrm{SD} .{ }^{*} p<0.05$ compared with DMSO control, ${ }^{*} p>0.05$ compared with curcumin control (7).

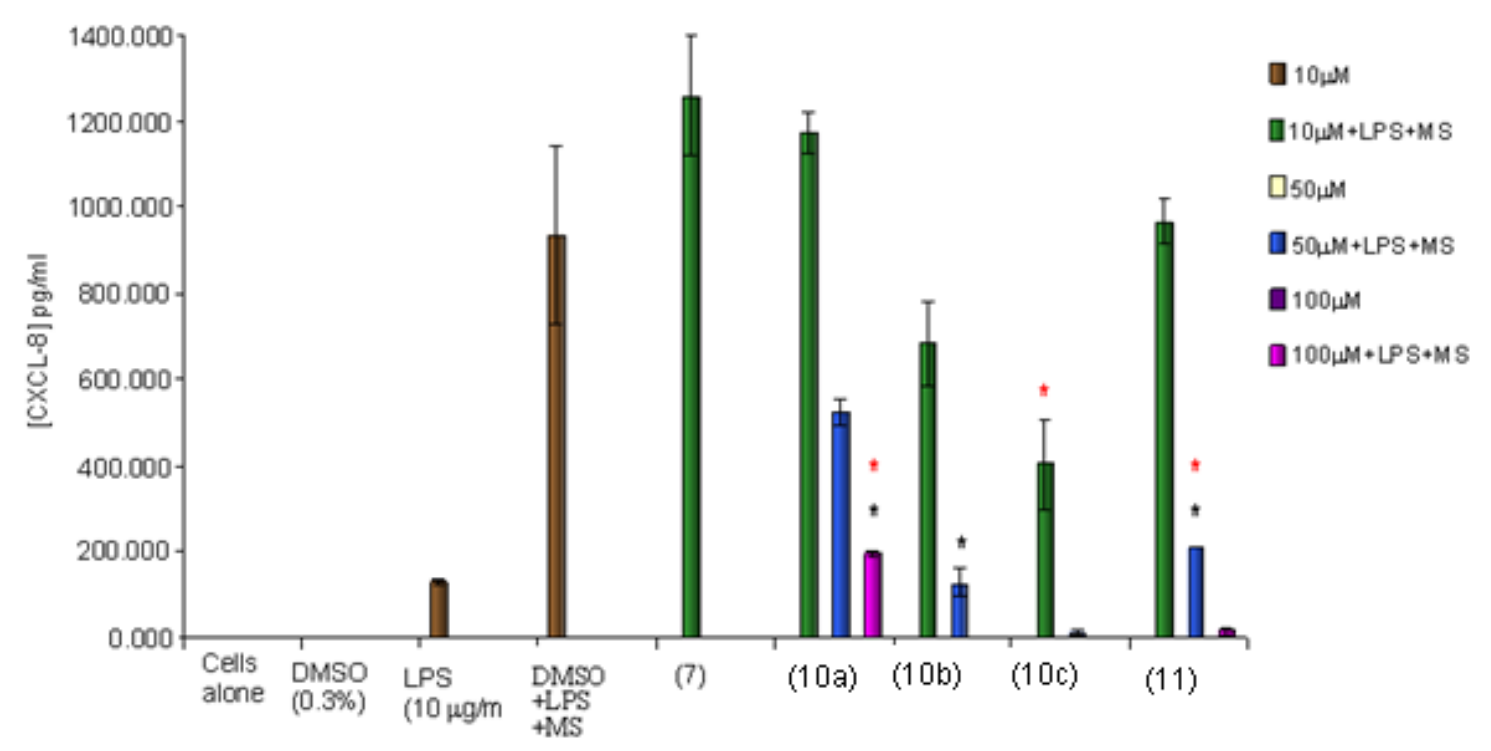

\section{Experimental}

\subsection{Chemistry: General}

All apparatus was oven-dried overnight prior to use. Ethanol and ethyl acetate were dried over molecular sieves, other solvents and chemicals were used as received without further purification. ${ }^{1} \mathrm{H}$-and ${ }^{13} \mathrm{C}$ - Nuclear magnetic resonance (NMR) spectra were recorded on a Bruker AC 250 spectrometer operating at 250 and $62.9 \mathrm{MHz}$, respectively, for solutions in deuterated chloroform, unless otherwise stated. Chemical shifts $(\delta)$ were recorded in parts per million $(\mathrm{ppm})$ relative to the reference, Tetramethylsilane (TMS) and coupling constants $(J)$ were calculated in Hz. Electron impact mass spectra (EIMS) were recorded on a VG 7070 Analytical Mass spectrometer. Electrospray mass spectra (ESMS) were obtained on Micromass platform single quadrupole mass spectrometer fitted with a Harvard syringe driver. The accurate mass of the compounds was detected using an Applied Biosystems/MDS Sciex Hybrid quadrupole time-of-flight instrument (Q-Star Pulsar-i) fitted with an orthogonal MALDI ion source and an ND:VAG Laser. Infrared spectra were recorded on ATI Mattson Genesis Series FTIR spectrophotometer using either potassium bromide pellets as a support for solid samples or sodium chloride disc for liquid samples. Melting points $\left({ }^{\circ} \mathrm{C}\right)$ were recorded on Stuart SMP 3 digital Electrothermal melting point apparatus and are uncorrected. The compounds/hydroxypropyl$\gamma$-cyclodextrin complexes were freeze-dried using a Thermo ModulyoD freeze-dryer. Curcumin (7) and curcuminoids $\mathbf{1 0 a}-\mathbf{c}$ have been previously reported [8].

\subsubsection{Preparation of tri-sec-Butyl Borate}

A mixture of powdered boric acid (12.4 gm; $0.2 \mathrm{~mol})$ and 2-butanol (44.4 gm; $0.6 \mathrm{~mol})$ in toluene $(120 \mathrm{~mL})$ was refluxed with azeotropic removal of water using a Dean-Stark apparatus. The toluene 
was evaporated on a rotary evaporator at $60{ }^{\circ} \mathrm{C}$ to give tri-sec-butyl borate as a clear liquid which was stored in a tightly sealed bottle. Acetyl acetone/boron oxide complex was prepared according to the method of Pabon [26].

\subsubsection{General Procedure for the Synthesis of Bromobutoxybenzaldehydes $\mathbf{6 a}-\mathbf{d}$}

All four compounds $\mathbf{6 a}-\mathbf{d}$ were synthesized by a typical procedure which is illustrated for the formation of compound 2-(4-bromobutoxy)benzaldehyde (6a). A three-neck round bottom flask fitted with a dropping-funnel, and a double surface condenser having a calcium chloride drying-tube was charged with dry EtOH $(60 \mathrm{~mL})$. Freshly cut sodium metal $(2.3 \mathrm{gm} ; 0.1 \mathrm{~mol})$ pre-washed in toluene was added slowly to EtOH with gentle stirring under reflux, until all the sodium had reacted. 2-Hydroxybenzaldehyde $(0.1 \mathrm{~mol})$ was added and the reaction mixture was heated at $80{ }^{\circ} \mathrm{C}$ for $30 \mathrm{~min}$. 1, 4-Dibromobutane (65 gm; $0.3 \mathrm{~mol}$ ) was added dropwise to the reaction mixture through a dropping funnel over a period of $35 \mathrm{~min}$. The reaction mixture was refluxed for $12 \mathrm{~h}$ after which the mixture was allowed to settle and then filtered by suction filtration on a Buchner flask. To the filtrate was added water $(60 \mathrm{~mL})$ and extracted with EtOAc $(2 \times 60 \mathrm{~mL})$. The organic layers were combined and dried over $\mathrm{MgSO}_{4}$, filtered and the solvent was evaporated on a rotary evaporator. The residue was distilled under reduced pressure (B.P. $45-50{ }^{\circ} \mathrm{C} / 8 \mathrm{mmHg}$ ) to remove the excess 1,4-dibromobutane and the crude product was purified by silica-gel flash chromatography using [pet. Ether-EtOAc (8:1 v/v)] as eluent, to yield product $\mathbf{2 a},(58 \%)$ as a light yellow oil, $R_{\mathrm{f}} 0.45$ [pet. ether-EtOAc, 5:1 v/v]. IR (v) 3075 (aromatic C-H stretch), 2932 (aliphatic C-H stretch), 2759 (aldehyde C-H stretch), 1687 (conjugated $>\mathrm{C}=\mathrm{O}$ stretch), 1598 and 1577 (aromatic $\mathrm{C}=\mathrm{C}$ stretch), 1242 (asymmetric $\mathrm{C}-\mathrm{O}-\mathrm{C}$ stretch), 1042 (symmetric C-O-C stretch), $758 \mathrm{~cm}^{-1}$ (ortho di-substituted out of plane C-H stretch); ${ }^{1} \mathrm{H}-\mathrm{NMR} \delta 1.89-2.17$ $\left(4 \mathrm{H}, \mathrm{m},-\mathrm{CH}_{2}-\mathrm{CH}_{2}-\right), 3.50\left(2 \mathrm{H}, \mathrm{t}, J=6.2 \mathrm{~Hz},-\mathrm{CH}_{2}-\mathrm{Br}\right), 4.11\left(2 \mathrm{H}, \mathrm{t}, J=5.6 \mathrm{~Hz},-\mathrm{O}-\mathrm{CH}_{2}-\right), 6.95-7.05$ $(2 \mathrm{H}, \mathrm{m}, \mathrm{Ar} \mathrm{H}-3$ and H-5), $7.53(1 \mathrm{H}, \mathrm{dt}, J=6.9$ and $1.5 \mathrm{~Hz}, \mathrm{Ar} \mathrm{H}-4), 7.82(1 \mathrm{H}, \mathrm{dd}, J=7.7$ and $1.5 \mathrm{~Hz}$, Ar H-6), 10.5 (1H, s, -CHO); EIMS m/z $256\left[\mathrm{M}^{79} \mathrm{Br}\right]^{+}(12 \%), 258$ [M $\left.^{81} \mathrm{Br}\right]^{+}$(12\%), 227 [M-CHO] ${ }^{+}$ $(3 \%), 135\left[\mathrm{C}_{4} \mathrm{H}_{8}{ }^{79} \mathrm{Br}\right]^{+}(62 \%), 137\left[\mathrm{C}_{4} \mathrm{H}_{8}{ }^{81} \mathrm{Br}\right]^{+}(59 \%), 121\left[\mathrm{C}_{7} \mathrm{H}_{5} \mathrm{O}_{2}\right]^{+}$(85\%); Accurate mass found: $m / z 256.0093\left(\mathrm{Br}^{79}\right)$, calculated for $\mathrm{C}_{11} \mathrm{H}_{13} \mathrm{O}_{2}{ }^{79} \mathrm{Br}: 256.0099$.

3-(4-Bromobutoxy)benzaldehyde (6b). Yield: 79\%, as a pale yellow oil, $R_{\mathrm{f}} 0.50$ [pet. Ether-EtOAc, 5:1 v/v]. IR (v) 3067 (aromatic C-H stretch), 2945 (aliphatic C-H stretch), 2729 (aldehyde C-H stretch), 1696 (conjugated $\mathrm{C}=\mathrm{O}$ stretch), 1596 and 1585 (aromatic $\mathrm{C}=\mathrm{C}$ stretch), 1262 (asymmetric C-O-C stretch), $1043 \mathrm{~cm}^{-1}$ (symmetric C-O-C stretch); ${ }^{1} \mathrm{H}-\mathrm{NMR} \delta 1.90-2.16\left(4 \mathrm{H}, \mathrm{m},-\mathrm{CH}_{2}-\mathrm{CH}_{2}-\right), 3.48(2 \mathrm{H}, \mathrm{t}$, $\left.J=6.4 \mathrm{~Hz},-\mathrm{CH}_{2}-\mathrm{Br}\right), 4.04\left(2 \mathrm{H}, \mathrm{t}, J=5.9 \mathrm{~Hz},-\mathrm{O}-\mathrm{CH}_{2}-\right), 7.11-7.46$ (4H, m, Ar H), 9.95 (1H, s, -CHO); EIMS $m / z$ : $256\left[\mathrm{M}^{79} \mathrm{Br}\right]^{+}$. $(7 \%), 258\left[\mathrm{M}^{81} \mathrm{Br}\right]^{+} .(7 \%), 135\left[\mathrm{C}_{4} \mathrm{H}_{8}{ }^{79} \mathrm{Br}\right]^{+}(71 \%), 137\left[\mathrm{C}_{4} \mathrm{H}_{8}{ }^{81} \mathrm{Br}\right]^{+}(69 \%)$, $121\left[\mathrm{C}_{7} \mathrm{H}_{5} \mathrm{O}_{2}\right]^{+}(69 \%)$; Accurate mass found: $\mathrm{m} / \mathrm{z} 256.0089$, calculated for $\mathrm{C}_{11} \mathrm{H}_{13} \mathrm{O}_{2}{ }^{79} \mathrm{Br}: 256.0099$.

4-(4-Bromobutoxy)benzaldehyde (6c). Yield: $81 \%$, as golden yellow oil, $R_{\mathrm{f}} 0.47$ [pet. Ether-EtOAc, 5:1 v/v]. IR (v) 3074 (aromatic C-H stretch), 2945 (aliphatic C-H stretch), 2738 (aldehyde C-H stretch), 1690 (conjugated $\mathrm{C}=\mathrm{O}$ stretch), 1600 and 1577 (aromatic $\mathrm{C}=\mathrm{C}$ stretch), 1255 (asymmetric C-O-C stretch), 1040 (symmetric C-O-C stretch), $832 \mathrm{~cm}^{-1}$ (para disubstituted out of plane $\mathrm{C}-\mathrm{H}$ stretch); ${ }^{1} \mathrm{H}-\mathrm{NMR} \delta 1.85-2.13\left(4 \mathrm{H}, \mathrm{m},-\mathrm{CH}_{2}-\mathrm{CH}_{2}-\right), 3.49\left(2 \mathrm{H}, \mathrm{t}, J=6.4 \mathrm{~Hz},-\mathrm{CH}_{2}-\mathrm{Br}\right), 4.08(2 \mathrm{H}, \mathrm{t}, J=5.9 \mathrm{~Hz}$, $\left.-\mathrm{O}-\mathrm{CH}_{2}-\right), 6.98(2 \mathrm{H}, \mathrm{d}, J=8.8 \mathrm{~Hz}, \mathrm{Ar} \mathrm{H}-3$ and H-3'), $7.82(2 \mathrm{H}, \mathrm{d}, J=8.3 \mathrm{~Hz}, \mathrm{Ar} \mathrm{H}-2$ and H-2'), 9.87 
$(1 \mathrm{H}, \mathrm{s},-\mathrm{CHO})$; EIMS m/z $256\left[\mathrm{M}^{79} \mathrm{Br}\right]^{+}(6 \%), 258\left[\mathrm{M}^{81} \mathrm{Br}\right]^{+} \cdot(6 \%), 135\left[\mathrm{C}_{4} \mathrm{H}_{8}{ }^{79} \mathrm{Br}\right]^{+}(58 \%), 137$ $\left[\mathrm{C}_{4} \mathrm{H}_{8}{ }^{81} \mathrm{Br}\right]^{+}(56 \%)$; Accurate mass found: $m / z$ 257.0176, calculated for $\mathrm{C}_{12} \mathrm{H}_{14} \mathrm{O}_{2}{ }^{79} \mathrm{Br}$ : 257.0171.

4-(4-Bromobutoxy)-3-methoxybenzaldehyde (6d). Yield: $50 \%$, as a white solid, $R_{\mathrm{f}} 0.33$ [pet. EtherEtOAc, 3:1 v/v], m.p. $49.7{ }^{\circ}$ C. IR (v) 3081 (aromatic C-H stretch), 2872 and 2933 (aliphatic C-H stretch), 2756 and 2821 (aldehyde $\mathrm{C}-\mathrm{H}$ stretch), 1679 (conjugated $\mathrm{C}=\mathrm{O}$ stretch), 1596 and 1584 (aromatic $\mathrm{C}=\mathrm{C}$ stretch), 1263 (asymmetric $\mathrm{C}-\mathrm{O}-\mathrm{C}$ stretch), $1046 \mathrm{~cm}^{-1}$ (symmetric C-O-C stretch); ${ }^{1} \mathrm{H}-\mathrm{NMR} \delta 2.06-2.08\left(4 \mathrm{H}, \mathrm{m},-\mathrm{CH}_{2}-\mathrm{CH}_{2}-\right), 3.51\left(2 \mathrm{H}, \mathrm{t}, J=6.4 \mathrm{~Hz},-\mathrm{CH}_{2}-\mathrm{Br}\right), 3.92\left(3 \mathrm{H}, \mathrm{s},-\mathrm{O}-\mathrm{CH}_{3}\right)$, $4.14\left(2 \mathrm{H}, \mathrm{t}, J=5.9 \mathrm{~Hz},-\mathrm{O}-\mathrm{CH}_{2}-\right), 6.96(1 \mathrm{H}, \mathrm{d}, J=7.7 \mathrm{~Hz}, \mathrm{Ar} \mathrm{H}-5), 7.40-7.46(2 \mathrm{H}, \mathrm{m}, \mathrm{Ar} \mathrm{H}-2$ and H-6), 9.85 (1H, s, -CHO); EIMS m/z $286\left[\mathrm{M}^{79} \mathrm{Br}\right]^{+} \cdot(9 \%), 288\left[\mathrm{M}^{81} \mathrm{Br}\right]^{+\cdot}(8 \%), 135\left[\mathrm{C}_{4} \mathrm{H}_{8}{ }^{79} \mathrm{Br}\right]^{+}(54 \%), 151$ $\left[\mathrm{C}_{4} \mathrm{H}_{8}{ }^{81} \mathrm{Br}\right]^{+}$(54\%); Accurate mass found: $\mathrm{m} / z 286.0200\left({ }^{79} \mathrm{Br}\right.$ ), calculated for $\mathrm{C}_{12} \mathrm{H}_{15} \mathrm{O}_{3}{ }^{79} \mathrm{Br}$ : 286.0205 .

\subsubsection{Synthesis of Curcuminoids}

Method A: In this procedure the synthesis of curcuminoids was carried out according to Pabon [8,21] in which separately prepared acetyl acetone-boron oxide complex was used.

Method B: In this procedure the synthesis of curcuminoids was carried out by the in-situ formation of acetyl-acetone-boron oxide complex.

The crude products $\mathbf{8 a}-\mathbf{d}$ obtained were all purified by flash column chromatography using [pet. Ether-EtOAc 8:1 v/v] as eluent.

(1E,4Z,6E)-1,7-Bis(2-94-bromobutoxy)phenyl)-5-hydroxyhepta-1,4,6-trien-3-one (8a). Yield: 34\% (method A), 21\% (method B), a dark brown gum, $R_{\mathrm{f}} 0.44$ [pet. ether-EtOAc, 3:1 v/v]. IR (KBr pellet) $v 3032$ (aromatic C-H stretch), 2924 (aliphatic C-H stretch), 1620 (H-bonded $>\mathrm{C}=\mathrm{O}$ stretch), 1595 and 1570 (aromatic $\mathrm{C}=\mathrm{C}$ stretch), 1244 (asymmetric C-O-C stretch), 1046 (symmetric C-O-C stretch), $750 \mathrm{~cm}^{-1}$ (ortho disubstituted out of plane $\mathrm{C}-\mathrm{H}$ stretch); ${ }^{1} \mathrm{H}-\mathrm{NMR} \delta 1.98-2.20,\left(8 \mathrm{H}, \mathrm{m},-\mathrm{CH}_{2}-\mathrm{CH}_{2}-\right), 3.55(4 \mathrm{H}, \mathrm{t}$, $\left.J=5.9 \mathrm{~Hz},-\mathrm{CH}_{2}-\mathrm{Br}\right), 4.10\left(4 \mathrm{H}, \mathrm{t}, J=5.6 \mathrm{~Hz},-\mathrm{O}-\mathrm{CH}_{2}-\right), 5.87(1 \mathrm{H}, \mathrm{s}$, enol H), $6.75(2 \mathrm{H}, \mathrm{d}, J=16.0 \mathrm{~Hz}$, $\operatorname{Ar}-\mathrm{C} \underline{H}=\mathrm{CH}-), 6.91(2 \mathrm{H}, \mathrm{d}, J=8.2 \mathrm{~Hz}, \mathrm{Ar} \mathrm{H}-3), 6.98(2 \mathrm{H}, \mathrm{t}, J=7.7 \mathrm{~Hz}, \mathrm{Ar} \mathrm{H}-5), 7.33$ (2H, dt, $J=8.7$ and $J=1.7 \mathrm{~Hz}$, Ar H-4), $7.57(2 \mathrm{H}, \mathrm{dd}, J=7.7$ and $J=1.5 \mathrm{~Hz}, \mathrm{Ar} \mathrm{H}-6), 7.97(2 \mathrm{H}, \mathrm{d}, J=16.0 \mathrm{~Hz}$, -CO-C $\underline{H}=\mathrm{CH}-\mathrm{Ar}) ;{ }^{13} \mathrm{C}-\mathrm{NMR} \delta 28.1,29.8,33.7,67.7,101.9,112.4,121.2,124.5,125.2,129.1,131.5$, 136.0, 157.9, 184.0; EIMS $m / z 576\left[\mathrm{M}^{79} \mathrm{Br}\right]^{+.}(4 \%), 580\left[\mathrm{M}^{81} \mathrm{Br}\right]^{+}$(6\%), $577[\mathrm{M}+\mathrm{H}]^{+},(2 \%), 578$, $[\mathrm{M}+2 \mathrm{H}]^{+},(7 \%), 135\left[\mathrm{C}_{4} \mathrm{H}_{8}{ }^{79} \mathrm{Br}\right]^{+}(39 \%), 137\left[\mathrm{C}_{4} \mathrm{H}_{8}{ }^{81} \mathrm{Br}\right]^{+}(37 \%)$; Accurate mass found: $m / z$ 577.0583, calculated for $\mathrm{C}_{27} \mathrm{H}_{31} \mathrm{O}_{4}{ }^{79} \mathrm{Br}_{2}: 577.0589$.

(1E,4Z,6E)-1,7-Bis(3-(4-bromobutoxy)phenyl)hepta-1,6-dien-3,5-dione (8b). Yield: $24 \%$ (method A) $21 \%(\operatorname{method} \mathrm{B})$, as a dark brown solid, $R_{\mathrm{f}} 0.41$ [pet. ether-EtOAc, 3:1 v/v], m.p. 74.6-75.9 ${ }^{\circ} \mathrm{C}$. IR $(\mathrm{v})$ 3426 (OH stretch), 3052 (aromatic C-H stretch), 2947 (aliphatic $\mathrm{C}-\mathrm{H}$ stretch), 1625 (H-bonded $>\mathrm{C}=\mathrm{O}$ stretch), 1596 and 1579 (aromatic $\mathrm{C}=\mathrm{C}$ stretch), 1508 (enol), 1243 (asymmetric C-O-C stretch), 1044 (symmetric C-O-C stretch), 885, 791, $677 \mathrm{~cm}^{-1}$ (meta disubstituted out of plane C-H stretch); ${ }^{1} \mathrm{H}-\mathrm{NMR}$ $\delta$ 1.95-2.18 (8H, m, $\left.-\mathrm{CH}_{2}-\mathrm{CH}_{2}-\right), 3.51\left(4 \mathrm{H}, \mathrm{t}, J=6.45 \mathrm{~Hz},-\mathrm{CH}_{2}-\mathrm{Br}\right), 4.04\left(4 \mathrm{H}, \mathrm{t}, J=5.9 \mathrm{~Hz},-\mathrm{O}-\mathrm{CH}_{2}-\right)$, $5.85(1 \mathrm{H}, \mathrm{s}$, enol H), $6.62(2 \mathrm{H}, \mathrm{d}, J=16.0 \mathrm{~Hz}, \mathrm{Ar}-\mathrm{C} \underline{\mathrm{H}}=\mathrm{CH}-), 6.92(2 \mathrm{H}, \mathrm{d}, J=7.7 \mathrm{~Hz}, \mathrm{Ar} \mathrm{H}-4), 7.07$ $(2 \mathrm{H}, \mathrm{s}, \mathrm{Ar} \mathrm{H}-2), 7.16(2 \mathrm{H}, \mathrm{d}, J=7.7 \mathrm{~Hz}, \mathrm{Ar} \mathrm{H}-6), 7.31(2 \mathrm{H}, \mathrm{t}, J=7.9 \mathrm{~Hz}, \mathrm{Ar} \mathrm{H}-5), 7.63$ (2H, d, $J=16.0 \mathrm{~Hz},-\mathrm{CO}-\mathrm{C} \underline{H}=\mathrm{CH}-\mathrm{Ar}) ;{ }^{13} \mathrm{C}-\mathrm{NMR} \delta 28.1,29.8,33.6,67.2,102.0,113.9,116.7,121.2,124.7$, 
130.2, 136.7, 140.8, 159.5, 183.5; ESMS $m / z 576\left[\mathrm{M}^{79} \mathrm{Br}\right]^{+}, 577\left[\mathrm{M}^{79} \mathrm{Br}+\mathrm{H}\right]^{+}, 578\left[\mathrm{M}{ }^{79} \mathrm{Br}+2 \mathrm{H}\right]^{+}$, $580\left[\mathrm{M}^{81} \mathrm{Br}\right]^{+}, 581\left[\mathrm{M}^{81} \mathrm{Br}+\mathrm{H}\right]^{+}, 582,\left[\mathrm{M}^{81} \mathrm{Br}+2 \mathrm{H}\right]^{+}$.

(1E,6E)-1,7-Bis(4-(4-bromobutoxy)phenyl)hepta-1,6-dien-3,5-dione (8c). Yield: 66\% (method A), $41 \%(\operatorname{method} \mathrm{B})$, as a bright yellow solid, $R_{\mathrm{f}} 0.42$ [pet. ether-EtOAc, $3: 1 \mathrm{v} / \mathrm{v}$ ], m.p. $145-146.9{ }^{\circ} \mathrm{C}$. IR (v) 3433 (OH stretch), 3035 (aromatic C-H stretch), 2945 (aliphatic C-H stretch), 1628 (H-bonded $>\mathrm{C}=\mathrm{O}$ stretch), 1600 (aromatic $\mathrm{C}=\mathrm{C}$ stretch), 1510 (enol), 1420 (olefinic in plane bending vibration), 1257 (asymmetric C-O-C stretch), 1046 (symmetric C-O-C stretch), $837 \mathrm{~cm}^{-1}$ (para disubstituted out of plane C-H stretch); ${ }^{1} \mathrm{H}$ NMR $\delta 1.92-2.14\left(8 \mathrm{H}, \mathrm{m},-\mathrm{CH}_{2}-\mathrm{CH}_{2}-\right), 3.50\left(4 \mathrm{H}, \mathrm{t}, J=6.4 \mathrm{~Hz},-\mathrm{CH}_{2}-\mathrm{Br}\right)$, $4.04\left(4 \mathrm{H}, \mathrm{t}, J=5.6 \mathrm{~Hz},-\mathrm{O}-\mathrm{CH}_{2}-\right), 5.78(1 \mathrm{H}, \mathrm{s}$, enolic $\mathrm{CH}=\mathrm{C}), 6.50(2 \mathrm{H}, \mathrm{d}, J=15.5 \mathrm{~Hz}, \mathrm{Ar}-\mathrm{C} \underline{H}=\mathrm{CH}-)$, $6.90(4 \mathrm{H} \mathrm{d} J=8.8 \mathrm{~Hz}, \mathrm{Ar} \mathrm{H}-3$ and H3'), $7.50(4 \mathrm{H}, \mathrm{d}, J=8.7 \mathrm{~Hz}, \mathrm{Ar} \mathrm{H}-2$ and H2'), 7.62 (2H, d, $J=15.5 \mathrm{~Hz},-\mathrm{CO}-\mathrm{C} \underline{\mathrm{H}}=\mathrm{CH}-\mathrm{Ar}) ;{ }^{13} \mathrm{C}-\mathrm{NMR} \delta 29.7,28.1,67.3,101.6,115.1,122.1,128.3,130.0,140.3$, 160.8, 183.6; EIMS m/z $576\left[\mathrm{M}^{79} \mathrm{Br}\right]^{+}(3 \%), 578\left[\mathrm{M}^{79} \mathrm{Br}+2 \mathrm{H}\right]^{+}(8 \%), 135,\left[\mathrm{C}_{4} \mathrm{H}_{8}{ }^{79} \mathrm{Br}\right]^{+}(100 \%), 137$ $\left[\mathrm{C}_{4} \mathrm{H}_{8}{ }^{81} \mathrm{Br}\right]^{+}$(98\%); Accurate mass found: $\mathrm{m} / z$ 576.0535, calculated for $\mathrm{C}_{27} \mathrm{H}_{30} \mathrm{O}_{4}{ }^{79} \mathrm{Br}_{2}: 576.0511$ ).

(1E,4Z,6E)-1,7-Bis(4-(4-bromobutoxy)-3-methoxyphenyl)hepta-1,6-dien-3,5-dione (8d). Yield: 57\% (method A), as a dark yellow solid between EtOAc and aqueous layers during work-up and no further purification was required; $R_{\mathrm{f}} 0.38$ [pet. ether-EtOAc, $2: 1 \mathrm{v} / \mathrm{v}$ ], m.p. $124.4-125.4{ }^{\circ} \mathrm{C}$. IR (v) $3548-3235$ (OH enolic), 3003 (aromatic C-H stretch), 2955 and 2870 (aliphatic C-H stretch), 1620 (H-bonded $>\mathrm{C}=\mathrm{O}$ ), 1597 and 1581 (aromatic $\mathrm{C}=\mathrm{C}$ stretch), 1508 (enol), $1422 \mathrm{~cm}^{-1}$ (olefinic in plane bending vibration); ${ }^{1} \mathrm{H}-\mathrm{NMR} \delta 2.00-2.17\left(8 \mathrm{H}, \mathrm{m},-\mathrm{CH}_{2}-\mathrm{CH}_{2}-\right), 3.51\left(4 \mathrm{H} \mathrm{t}, J=6.4 \mathrm{~Hz},-\mathrm{CH}_{2}-\mathrm{Br}\right), 3.92(6 \mathrm{H}, \mathrm{s}$, $\left.-\mathrm{OCH}_{3}\right), 4.10\left(4 \mathrm{H}, \mathrm{t}, J=5.9 \mathrm{~Hz},-\mathrm{O}-\mathrm{CH}_{2}-\right), 5.82(1 \mathrm{H}, \mathrm{s}$, enol $\mathrm{H}), 6.50(2 \mathrm{H}, \mathrm{d}, J=16.0 \mathrm{~Hz}$, $\operatorname{Ar}-\mathrm{C} \underline{H}=\mathrm{CH}-), 6.87(2 \mathrm{H}, \mathrm{d}, J=8.2 \mathrm{~Hz}, \mathrm{Ar} \mathrm{H}-5), 7.08(2 \mathrm{H}, \mathrm{d}, J=2.0 \mathrm{~Hz}, \operatorname{Ar} \mathrm{H}-2), 7.13$ (2H, dd, $J_{1,3}=8.2$ and $\left.J_{1,2}=1.5 \mathrm{~Hz}, \mathrm{Ar} \mathrm{H}-6\right), 7.61(2 \mathrm{H}, \mathrm{d}, J=15.5 \mathrm{~Hz},-\mathrm{CO}-\mathrm{C} \underline{H}=\mathrm{CH}-\mathrm{Ar})$; EIMS $m / z 637$ $[\mathrm{M}+\mathrm{H}]^{+}(18 \%), 619\left[\mathrm{M}+\mathrm{H}-\mathrm{H}_{2} \mathrm{O}\right]^{+}(31 \%), 324\left[\mathrm{C}_{15} \mathrm{H}_{18} \mathrm{O}_{3}{ }^{79} \mathrm{Br}+\mathrm{H}\right]^{+}(31 \%), 326\left[\mathrm{C}_{15} \mathrm{H}_{18} \mathrm{O}_{3}{ }^{81} \mathrm{Br}+\mathrm{H}\right]^{+}$ (29\%), $324\left[\mathrm{C}_{14} \mathrm{H}_{16} \mathrm{O}_{3}{ }^{79} \mathrm{Br}\right]^{+}(20 \%), 313\left[\mathrm{C}_{14} \mathrm{H}_{16} \mathrm{O}_{3}{ }^{81} \mathrm{Br}\right]^{+}(18 \%), 135\left[\mathrm{C}_{4} \mathrm{H}_{8}{ }^{79} \mathrm{Br}\right]^{+}(100 \%), 137\left[\mathrm{C}_{4} \mathrm{H}_{8}\right.$ $\left.{ }^{81} \mathrm{Br}\right]^{+}$(99\%); Accurate mass found: $m / z 636.0714\left(\mathrm{Br}^{79}\right)$, calculated for $\mathrm{C}_{29} \mathrm{H}_{34} \mathrm{O}_{6}{ }^{79} \mathrm{Br}_{2}: 636.0722$.

\subsubsection{Synthesis of Nitroxybutyl Curcuminoids 9a-d}

The general procedure for the synthesis of butoxy-nitrate curcuminoids $9 \mathbf{a}-\mathbf{d}$ is illustrated for the formation of (1E,6E)-1,7-bis(2-(4-butoxynitrato)hepta-1,6-diene-3,5-dione (9a). In a one-neck round bottom flask, a mixture of silver nitrate $(1.17 \mathrm{gm}, 6.9 \mathrm{mmol})$ in acetonitrile $(3 \mathrm{~mL})$ was stirred for 30 min. and then a solution of $\mathbf{8 a}(0.86 \mathrm{mmol})$ in acetonitrile $(2 \mathrm{~mL})$ was added. The reaction mixture was refluxed under stirring for $5 \mathrm{~h}$ at $80{ }^{\circ} \mathrm{C}$. An aluminium sheet was wrapped round the flask to protect it from light and the mixture was allowed to stand overnight. Water $(5 \mathrm{~mL})$ was added and after filtration the mixture was extracted with EtOAc $(2 \times 30 \mathrm{~mL})$. The organic layers were combined, dried over $\mathrm{MgSO}_{4}$, filtered under gravity and the solvent was removed on the rotary evaporator to yield pure 9a $(90 \%)$ as a dark brown gum, $R_{\mathrm{f}} 0.43$ [pet. ether-EtOAc, $2: 1 \mathrm{v} / \mathrm{v}$ ], m.p. $136.0-136.8^{\circ} \mathrm{C}$. IR (KBr pellet) v 3035 (aromatic C-H stretch), 2926 and 2878 (aliphatic $\mathrm{C}-\mathrm{H}$ stretch), 1625 (conjugated $>\mathrm{C}=\mathrm{O}$ stretch), 1596 and 1488 (aromatic $\mathrm{C}=\mathrm{C}$ stretch), 1472 and 1280 (aliphatic $\mathrm{NO}_{2}$ stretch), $1455\left(\mathrm{CH}_{2}\right.$ bending absorption), 1244 (asymmetric C-O-C stretch), 1049 (symmetric C-O-C stretch), $753 \mathrm{~cm}^{-1}$ (ortho disubstituted out of plane $\mathrm{C}-\mathrm{H}$ stretch); ${ }^{1} \mathrm{H}-\mathrm{NMR} \delta 1.99-2.04\left(8 \mathrm{H}, \mathrm{m},-\mathrm{CH}_{2}-\mathrm{CH}_{2}-\right), 4.10(4 \mathrm{H}, \mathrm{t}$, 
$\left.J=5.4 \mathrm{~Hz},-\mathrm{O}-\mathrm{CH}_{2}-\right), 4.58\left(4 \mathrm{H}, \mathrm{t}, J=5.9 \mathrm{~Hz},-\mathrm{CH}_{2}-\mathrm{ONO}_{2}\right), 5.83(1 \mathrm{H}, \mathrm{s}$, enol H), $6.74(2 \mathrm{H}, \mathrm{d}, J=16.0 \mathrm{~Hz}$, Ar-C $\underline{H}=\mathrm{CH}-), 6.91(2 \mathrm{H}, \mathrm{d}, J=8.2 \mathrm{~Hz}, \mathrm{Ar} \mathrm{H}-3), 6.99(2 \mathrm{H}, \mathrm{t}, J=7.4 \mathrm{~Hz}, \mathrm{Ar} \mathrm{H}-7.97(2 \mathrm{H}, \mathrm{d}, J=16.0 \mathrm{~Hz}$, -CO-C $\underline{H}=\mathrm{CH}-\mathrm{Ar}) ;{ }^{13} \mathrm{C}-\mathrm{NMR} \delta 24.2,25.9,67.8,73.1,102.1,112.4,121.3,124.6,125.2,129.0,131.5$, 135.8, 157.7, 183.9; ESMS m/z $543[\mathrm{M}+\mathrm{H}]^{+}$, $332\left[\mathrm{C}_{17} \mathrm{H}_{18} \mathrm{O}_{6} \mathrm{~N}\right]^{+}$; Accurate mass found: $m / z$ 543.1964, calculated for $\mathrm{C}_{27} \mathrm{H}_{31} \mathrm{~N}_{2} \mathrm{O}_{10}: 543.1973$.

(1E,6E)-1,7-Bis(3-(4-butoxy-nitrate)hepta-1,6-diene-3,5-dione (9b). Yield: 58\% as a dark brown solid, $R_{\mathrm{f}} 0.46$ [pet. ether-EtOAc, 2:1 v/v], m.p. 133.9-134.9 ${ }^{\circ} \mathrm{C}$. IR (v) 3414 (OH stretch), 3020 (aromatic C-H stretch), 2929 and 2875 (aliphatic $\mathrm{C}-\mathrm{H}$ stretch), 1638 (conjugated $>\mathrm{C}=\mathrm{O}$ stretch), 1596 and 1489 (aromatic $\mathrm{C}=\mathrm{C}$ stretch), 1473 and 1279 (aliphatic $\mathrm{NO}_{2}$ stretch), $1458\left(\mathrm{CH}_{2}\right.$ bending absorption), 1247 (asymmetric C-O-C stretch), $1041 \mathrm{~cm}^{-1}$ (symmetric C-O-C stretch); ${ }^{1} \mathrm{H}-\mathrm{NMR} \delta 1.95(8 \mathrm{~Hz}, \mathrm{t}, J=2.8 \mathrm{~Hz}$, $\left.-\mathrm{CH}_{2}-\mathrm{CH}_{2}-\right), 4.04\left(4 \mathrm{H}, \mathrm{t}, J=5.1 \mathrm{~Hz},-\mathrm{O}-\mathrm{CH}_{2}-\right), 4.56\left(4 \mathrm{H}, \mathrm{t}, J=5.9 \mathrm{~Hz},-\mathrm{CH}_{2}-\mathrm{ONO}_{2}\right), 5.85(1 \mathrm{H}$, s, enol $\mathrm{H}), 6.61(2 \mathrm{H}, \mathrm{d}, J=16.0 \mathrm{~Hz}, \mathrm{Ar}-\mathrm{C} \underline{\mathrm{H}}=\mathrm{CH}-), 6.91(2 \mathrm{H}, \mathrm{dd}, J=7.9$ and $1.7 \mathrm{~Hz}, \mathrm{Ar} \mathrm{H}-4), 7.06$ (2H, s, Ar $\mathrm{H}-2), 7.16(2 \mathrm{H}, \mathrm{d}, J=7.7 \mathrm{~Hz}, \operatorname{Ar} \mathrm{H}-6), 7.31(2 \mathrm{H}, \mathrm{t}, J=7.7 \mathrm{~Hz}, \operatorname{Ar} \mathrm{H}-5), 7.62(2 \mathrm{H}, \mathrm{d}, J=15.5 \mathrm{~Hz}$, -CO-C $\underline{H}=\mathrm{CH}-\mathrm{Ar}) ;{ }^{13} \mathrm{C}-\mathrm{NMR}: \delta$ 24.2, 25.9, 67.3, 73.1, 102.1, 113.9, 116.6, 121.3, 124.7, 130.3, 136.7, 140.7, 159.4, 183.5; ESMS m/z $543[\mathrm{M}+\mathrm{H}]^{+}$, $565[\mathrm{M}+\mathrm{Na}]^{+}$; Accurate mass found: $\mathrm{m} / z$ 543.1985, calculated for $\mathrm{C}_{27} \mathrm{H}_{31} \mathrm{~N}_{2} \mathrm{O}_{10}: 543.1973$.

(1E,6E)-1,7-Bis(4-(4-Butoxy-nitrate)hepta-1,6-diene-3,5-dione (9c). Yield: 95\%, golden yellow solid, $R_{\mathrm{f}} 0.35$ (pet. ether-EtOAc, 2:1 v/v), m.p. 112.6-113 ${ }^{\circ} \mathrm{C}$. IR (v) 3412 (OH stretch), 3040 (aromatic C-H stretch), 2936 (aliphatic $\mathrm{C}-\mathrm{H}$ stretch), 1620 (conjugated $>\mathrm{C}=\mathrm{O}$ stretch), 1603 and 1511 (aromatic $\mathrm{C}=\mathrm{C}$ stretch), 1472 and 1287 (aliphatic $\mathrm{NO}_{2}$ stretch), 1256 (asymmetric C-O-C stretch), 1056 (symmetric C-O-C stretch), $837 \mathrm{~cm}^{-1}$ (para disubstituted out of plane C-H stretch); ${ }^{1} \mathrm{H}-\mathrm{NMR} \delta 1.95(8 \mathrm{H}, \mathrm{t}, \mathrm{J}=2.2 \mathrm{~Hz}$, $\left.-\mathrm{CH}_{2}-\mathrm{CH}_{2}-\right), 4.06\left(4 \mathrm{H}, \mathrm{t}, J=5.6 \mathrm{~Hz},-\mathrm{O}-\mathrm{CH}_{2}-\right), 4.56\left(4 \mathrm{H}, \mathrm{t}, J=5.3 \mathrm{~Hz},-\mathrm{CH}_{2}-\mathrm{ONO}_{2}\right), 5.79(1 \mathrm{H}$, s, enol $\mathrm{H}), 6.51(2 \mathrm{H}, \mathrm{d}, J=15.5 \mathrm{~Hz}, \mathrm{Ar}-\mathrm{CH}=\mathrm{CH}-), 6.90(4 \mathrm{H}, \mathrm{d}, J=8.8 \mathrm{~Hz}, \mathrm{Ar} \mathrm{H}-3$ and H-3'), 7.51 (4H, d, $J=8.8 \mathrm{~Hz}, \mathrm{Ar} \mathrm{H}-2$ and H-2'), $7.63(2 \mathrm{H}, \mathrm{d}, J=16.0 \mathrm{~Hz},-\mathrm{CO}-\mathrm{C} \underline{\mathrm{H}}=\mathrm{CH}-\mathrm{Ar}) ;{ }^{13} \mathrm{C}-\mathrm{NMR}: \delta 24.1,25.8$, $67.4,73.1,101.6,115.1,122.2,128.3,130.0,140.3,160.7,183.6$; EIMS $m / z 543[\mathrm{M}+\mathrm{H}]^{+},(42 \%)$.

(1E,6E)-1,7-Bis(4-(4-butoxy-nitrate)-3-methoxyphenyl)hepta-1,6-diene-3,5-dione (9d). Yield: 92\% as an orange solid, $R_{\mathrm{f}} 0.43$ [pet. ether-EtOAc, $1: 3 \mathrm{v} / \mathrm{v}$ ], m.p. $101.6-102.6{ }^{\circ} \mathrm{C}$. IR (v) $3436(\mathrm{OH}$ stretch), 2954 (aromatic C-H stretch), 2931 and 2873 (aliphatic $\mathrm{C}-\mathrm{H}$ stretch), 1621 (conjugated $>\mathrm{C}=\mathrm{O}$ stretch), $1458\left(\mathrm{CH}_{2}\right.$ bending absorption), 1512 (aromatic $\mathrm{C}=\mathrm{C}$ stretch), 1257 (asymmetric $\mathrm{C}-\mathrm{O}-\mathrm{C}$ stretch), 1027 (symmetric C-O-C stretch). ${ }^{1} \mathrm{H}-\mathrm{NMR} \delta 1.63\left(8 \mathrm{H}, \mathrm{s}, \mathrm{br} .-\mathrm{CH}_{2}-\mathrm{CH}_{2}-\right), 3.91\left(6 \mathrm{H}, \mathrm{s},-\mathrm{O}-\mathrm{CH}_{3}\right), 4.10(4 \mathrm{H}, \mathrm{t}$, $\left.J=5.1 \mathrm{~Hz},-\mathrm{O}-\mathrm{CH}_{2}-\right), 4.58\left(4 \mathrm{H}, \mathrm{t}, J=5.9 \mathrm{~Hz},-\mathrm{CH}_{2}-\mathrm{ONO}_{2}\right), 5.83(1 \mathrm{H}, \mathrm{s}$, enol H), $6.50(2 \mathrm{H}, \mathrm{d}, J=15.5 \mathrm{~Hz}$, Ar-C $\underline{H}=\mathrm{CH}-), 6.87(2 \mathrm{H}, \mathrm{d}, J=8.2 \mathrm{~Hz}, \mathrm{Ar} \mathrm{H}-5), 7.09$ (2H, s, Ar H-2 ), 7.13 (2H, d, $J=8.2 \mathrm{~Hz}, \mathrm{Ar}$ $\mathrm{H}-6), 7.61(2 \mathrm{H}, \mathrm{d}, J=15.5 \mathrm{~Hz},-\mathrm{CO}-\mathrm{C} \underline{\mathrm{H}}=\mathrm{CH}-\mathrm{Ar})$; EIMS $m / z 603[\mathrm{M}]^{+}(38 \%), 604[\mathrm{M}+\mathrm{H}]^{+},(12 \%)$; Accurate mass found: $m / z$ 603.2162, calculated for $\mathrm{C}_{29} \mathrm{H}_{35} \mathrm{~N}_{2} \mathrm{O}_{10}: 603.2184$.

1,7-Bis(thiophen-3-yl-)-1,6-heptadien-3,5,dione (11). Yield: 36\% (method A) purified by column chromatography (pet. ether-EtOAc, 6:1 v/v), 23\% yield (method B), yellow solid, $R_{\mathrm{f}} 0.48$ (pet. etherEtOAc, 5:1 v/v), m.p. 140.1-141.3 ${ }^{\circ} \mathrm{C}$; IR (v) 3435 (OH stretch), 3092 (aromatic C-H stretch), 1624 (H-bonded $>\mathrm{C}=\mathrm{O}$ ), 1584 (conjugated $\mathrm{C}=\mathrm{C}$ ), 1507 (enol), $1412 \mathrm{~cm}^{-1}$ (olefinic in plane bending vibration); ${ }^{1} \mathrm{H}-\mathrm{NMR} \delta 5.79$ (1H, s, enol H), 6.45 (2H, d, $\left.J=15.5 \mathrm{~Hz}, \mathrm{Ar}-\mathrm{C} \underline{\mathrm{H}}=\mathrm{CH}-\right), 7.33-7.38$ (4H, m, Ar 
H), $7.52(2 \mathrm{H}, \mathrm{d}, J=2.6 \mathrm{~Hz}, \mathrm{Ar} \mathrm{H}-2), 7.66(2 \mathrm{H}, \mathrm{d}, J=16.0 \mathrm{~Hz},-\mathrm{CO}-\mathrm{C} \underline{\mathrm{H}}=\mathrm{CH}-\mathrm{Ar})$; EIMS m/z 288 [M] (60\%), $270\left[\mathrm{M}-\mathrm{H}_{2} \mathrm{O}\right]^{+}$( $(8 \%), 192\left[\mathrm{C}_{10} \mathrm{H}_{8} \mathrm{O}_{2} \mathrm{~S}\right]^{+}(4 \%), 179\left[\mathrm{C}_{9} \mathrm{H}_{7} \mathrm{O}_{2} \mathrm{~S}\right]^{+}(5 \%), 151\left[\mathrm{C}_{8} \mathrm{H}_{7} \mathrm{OS}\right]^{+}(21 \%)$, $137\left[\mathrm{C}_{7} \mathrm{H}_{5} \mathrm{OS}\right]^{+}(100 \%), 109\left[\mathrm{C}_{6} \mathrm{H}_{5} \mathrm{~S}\right]^{+}(43 \%), 97\left[\mathrm{C}_{5} \mathrm{H}_{4} \mathrm{~S}\right]^{+}(21 \%)$; Accurate mass found: $\mathrm{m} / z$ 288.0277, calculated for $\mathrm{C}_{15} \mathrm{H}_{12} \mathrm{O}_{2} \mathrm{~S}_{2}: 288.0279$.

\subsection{Pharmacology}

\subsubsection{General Procedures for Cell Cultures And Compound Preparations}

Human monocytic leukemia (THP-1) cell line and human caucasian colon adenocarcinoma (CACO-2) cell lines were obtained from the European Collection of Cell Cultures (ECACC) (Salisbury, Wiltshire, UK). Preparation of drug treatments and general procedures for cell culture were as previously described [27-30]. All cell culture techniques, i.e., thawing, passaging, plating as well as respective compound treatments applied to the cells and cytotoxicity using 3-(4,5-dimethylthiazol2yl)-5-(3-carboxymethoxyphenyl)-2-(4-sulfophenyl)-2H-tetrazolium, inner salt (MTS) assays were performed under sterile conditions using a laminar flow cabinet. In these experiments the colorimetric assay CellTiter $96^{\circledR} \mathrm{AQ}$ ueous one solution cell proliferation in vitro was used to examine the effects of the synthesized curcumin (7) and curcuminoids on cell viability [27]. For experimental work, samples were prepared in media, without serum (serum-free RPMI) for THP-1 cells and CACO-2 cells respectively. Lipopolysaccharide (LPS) Escherichia coli O127:B8 (cell culture tested) and L-methionine sulfoximine (MS) were obtained from Sigma-Aldrich (St. Louis, MO, USA)). All incubations were carried out in a humidified incubator maintained at $37{ }^{\circ} \mathrm{C}$ with $5 \%(\mathrm{v} / \mathrm{v}) \mathrm{CO}_{2}$ and 95\% air. Experiments were performed in duplicate wells of the 96-well plates and were repeated at least four times unless otherwise stated in the figure legend.

For all MTS, nitric oxide and ELISAs, the stock solutions (33 mM) of all the compounds were prepared in DMSO (100\%) followed by appropriate dilutions. For the determination of cytotoxic effects of the compounds 9a-d these were complexed with hydroxypropyl- $\gamma$-cyclodextrin (HP- $\gamma$-CD) for improved solubilisation. A $100 \mathrm{mM}$ stock solution was prepared using DMSO (100\%). The drug/ HP- $\gamma$-CD complex (1:2 molar ratio) was diluted to 10,50 and $100 \mu \mathrm{M}$ (relative to the drug concentration) [27].

\subsubsection{Nitric Oxide Assay}

The determination of nitrite in biological samples was measured by the spectrophotometric method using Griess reagent. NO levels are quantified by estimating its stable end product (nitrite anion) which is formed as a result of nitric oxide oxidation [31]. Experimental samples (50 $\mu \mathrm{L} / \mathrm{well})$ were added to duplicate wells of a 96-well plate, $50 \mu \mathrm{L}$ of Griess reagent was then added and samples incubated for 5-10 min at room temperature protected from light for colour development. Absorbance was measured at $570 \mathrm{~nm}$ using a plate reader (Wallac Victor 2 multi-label plate reader). Nitrite concentrations were determined from a sodium nitrite standard curve. 


\subsubsection{Sandwich ELISA Assay}

Sandwich ELISAs are a widely used standard method for the quantitative detection of cytokines and other specific proteins in serum samples. Substrate was added which reacted with the enzyme producing a colour change, the intensity of which is directly proportional to the concentration of antigen in incubation mixture allowing its spectrophotometric detection and quantification. Standard proteins of known concentrations are incorporated into the assay to allow quantification of specific proteins to be determined [32-34]. The capture antibodies, mouse anti-human IL-1 $\beta$ or mouse anti-human TNF- $\alpha$ were diluted to a working concentration of $4.0 \mu \mathrm{g} / \mathrm{ml}$ in PBS (without carrier proteins). ELISA flat-bottom 96-well plates were prepared according to the manufacturer's protocol for the detection of IL- $1 \beta$ or TNF- $\alpha$ in cell supernatants of THP-1, CXCL-8 and CACO- 2 cells. An ELISA flat-bottom 96-well plate was immediately coated with $100 \mu \mathrm{L} /$ well of the diluted capture antibody, sealed and incubated overnight at room temperature. Next day, each well of the 96-well micro plate was aspirated and washed six times with wash buffer (WB, 0.05\% Tween ${ }^{\circledR} 20$ in PBS). After the last wash, the plate was dried by blotting against clean paper towel, blocked by adding $300 \mu \mathrm{L} /$ well of reagent diluent (RD) (1\%).

The 96-well microtitre plate is coated with capture antibody (1st antibody) and the target protein or antigen is added. Detection antibody (2nd antibody) is added followed by the addition of enzyme, horseradish peroxidase (HRP)-linked antibody. Substrate solution containing colorimetric substrate, 3,3',5,5'-tetramethylbenzidine (TMB) and hydrogen peroxide $\left(\mathrm{H}_{2} \mathrm{O}_{2}\right)$ is added. TMB reacts with $\mathrm{H}_{2} \mathrm{O}_{2}$ in the presence of HRP enzyme to produce a water-soluble, blue coloured by-product the intensity of which is proportional to the amount of HRP activity, which in turn is related to the levels of target analyte in the experimental sample. Upon acidification with sulphuric-acid (stop solution) the colour changes from blue to yellow, enabling accurate measurement of the intensity at $450 \mathrm{~nm}$ using a plate-reader.

\section{Acknowledgements}

We thank Nicola Woodroofe for use of facilities in the BMRC and some financial support. We also thank Rowena Bunning for proof reading the paper and for her valuable suggestions. There is no conflict of interest to disclose.

\section{References}

1. Aggarwal, B.B., Surh, Y.J., Shishodia, S., Eds. The Molecular Targets and Therapeutic Uses of Curcumin in Health and Disease. Springer: New York, NY, USA, 2007.

2. Braun, L; Cohen; N. Herbs and Natural Supplements: An. Evidence-Based Guide. Elsevier-Mosby: Sydney, Australia, 2004; pp. 358-368.

3. Srimal, R.C.; Dhawan, B.N. Pharmacology of Diferuoyl Methane (Curcumin). A Non-steroidal Anti-inflammatory Agent. J. Pharm. Pharmacol. 1973, 25, 447-452.

4. Nurfina, A.N.; Reksohadiprodja, M.S.; Timmerman, H.; Jenie, U.A.; Sugiyaanto, D.; van der Goot, H. Synthesis of some symmetrical curcumin derivatives and their antiinflammatory Activity. Eur. J. Med. Chem. 1997, 32, 321-3285.

5. Mukhopadhyay, A.; Basu, N.; Ghatak, N.; Gujral, P.K. Antiinflammatory and Irritant Activities of Curcumin Analogs in Rats. Agents Actions 1982, 12, 508-515. 
6. Jackson, J.K.; Higo,T.; Hunter ,W.L.; Burt, H.M. The antioxidants curcumin and quercetin Inhibit inflammatory processes associated with arthritis. Inflamm. Res. 2006, 55, 168-175.

7. Anand, P.; Sundaram, C.; Jhurani, S.; Kunnumakkara, A.B.; Aggarwal, B.B. Curcumin and cancer: An "old age" desease with an "age old" solution. Cancer Lett. 2008, 267, 133-164.

8. Khan, M.A.; El-Khatib, R.; Rainsford, K.D.; Whitehouse, M.W. Synthesis and anti-inflammatory properties of some aromatic and heterocyclic aromatic curcuminoids. Bioorg. Chem. 2012, 40, 30-38.

9. Wallace, J.L.; Reuter, B. Cicala, C.; McKnight, W.; Grisham, M.; Cirino, G. A diclofenac derivative without ulcerogenic properties. Eur. J. Pharmacol. 1994, 257, 249-255.

10. Arena, B; Del Soldato, P. Nitric esters having a pharmacological activity and process for their preparation. US Patents 5,621,000, 15 April 1997.

11. Del Sodato, P. Nitric esters having anti-inflammatory and/or analgesic activity and process for their preparation. US Patents 5,780,495, 14 July 1997.

12. Chiroli, V.; Benedini, F.; Ongini, E.; Del Soldato, P. Nitric oxide-donating non-steroidal anti-inflammatory drugs: the case of nitroderivatives of aspirin. Eur. J. Med. Chem. 2003, 38, 441-446.

13. Fiorucci, S.; Antonelli, E. Dual COX-inhibitors: the answer is NO. Curr. Top. Med. Chem. 2005, 5, 487-492.

14. Bolla, M.; Almirante, N.; Benedini, F. therapeutic potential of nitrate esters of commonly used drugs. Curr. Top. Med. Chem. 2005, 5, 707-720.

15. Rigas, B.; Kashfi, K. Nitric oxide donating NSAIDs as agents for cancer prevention. Trends Mol. Med. 2004, 10, 324-330.

16. Davies, N.M., Roseth, A.G., Appleyard, C.B., McKnight, W.; Del Soldato, P.; Calignano, A.; Cirino, G.; Wallace, J.L. NO-naproxen vs naproxen: Ulcerogenic, Alalgesic and anti-inflammatory effects. Aliment. Pharmacol. Ther. 1997, 11, 69-79.

17. Nemmani, K.V.S.; Mali, S.V.; Borhade, N.; Pathan, A.R.; Karwa, M.; Pamidiboina, V.; Senthilkumar, S.P.; Gund, M.; Jain, A.K.; Mangu, N.K.; et al. NO-NSAIDs: Gastric-sparing nitric oxide-releasable prodrugs of non-steroidal anti-inflammatory drugs, Bioorg. Med. Chem. Lett. 2009, 19, 5297-5301.

18. Borhade, N.; Pathan, A.R.; Halder, S.; Karwa, M.; Dhiman, M.; Pamidiboina, V.; Gund, M.; Deshattiwar, J.J.; Mali, S.V.; Deshmukh, N.J.; et al. NO-NSAIDs. Part 3: Nitric Oxide-Releasing Prodrugs of Non-steroidal Anti-inflammatory Drugs. Chem. Pharm. Bull. 2012, 60, 465-481.

19. Ranatunge, R.R.; Augustyniak, M.; Bandarage, U.K.; Cochran, E.D.; Earle, R.A.; Ellis, J.L.; GarveyY, D.S.; Janero, D.R.; Letts, L.G.; Martino, A.M.; et al. Synthesis and selective cycoloxygenase-2 inhibitory activity of a series of novel nitric oxide donor-containing pyrazoles. J. Med. Chem. 2004, 47, 2180-2193.

20. Viola, A., Luster, A.D. Chemokines and their receptors: Drug targets in immunity and inflammation. Annu. Rev. Pharmacol. Toxicol. 2008, 48, 171-197.

21. Hsu, H.-Y.; Chu, L.-C.; Hua, K.-F.; Chao, L.-K. Heme oxygenase-1 mediates the anti-inflammatory effect of curcumin within LPS-stimulated human monocytes. J. Cell. Physiol. 2008, 215, 603-612. 
22. Dhawan, V.; Schwalb, D.J.; Shumway, M.J.; Warren, M.C.; Wexler, R.S.; Zemtseva, I.S.; Zifcak, B.M.; Janero, D.R. Selective nitros(yl)ation induced in vivo by a nitric oxide-donating cyclooxygenase-2 inhibitor: A Nobonomic analysis. Free Radical Bio. Med. 2005, 39, 1191-1207.

23. Dinarello, C.A. A clinical perspective of IL-1 beta as the gatekeeper of inflammation. Eur. J. Immunol. 2001, 41, 1203-1217.

24. Pfeffer, K. Biological function of tumor necrosis factor cytokines and their receptors. Cytokine Growth F. R. 2003, 14, 185-191.

25. Abaza, M.S.; Khan, M.A.; Afzal, M. Chemistry, Biochemistry and Selective Cytotoxicity of Curcumin Analogues Against Human Cancer Cell Lines. In Curcumin: Biosynthesis, Medicinal Uses and Health Benefits; Sasaki, J., Kichida, M., Eds.; Nova Science Publishers Inc.: Hauppauge, NY, USA, 2012.

26. Pabon, H.J.J. Synthesis of curcumin and related compounds. Recueil Des. Travaux Chimiques Des. Pays Bas 1964, 83, 379-386.

27. Huang, Y.; Li, N.; Liboni, K.; Neu, J. Glutamine decreases lipopolysaccharide-induced IL-8

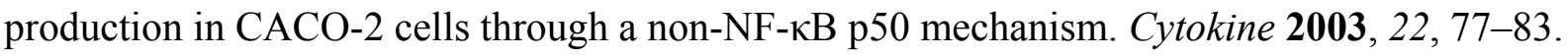

28. Rainsford, K.D.; Omar, H.; Ashraf, A.; Hewson, A.T.; Bunning, R.A.D.; Rishiraj, R.; Shepherd, P.; Seabrook, R.W. Recent pharmacokinetic and pharmacodynamic findings on oxaprozin. Inflammopharmacology 2002, 10, 185-239.

29. Miranda, K.M.; Espey, M.G.; Wink, D.A. A rapid, Simple spectrophotometric method for simultaneous detection of nitrate and nitrite. Nitric Oxide 2001, 5, 62-71.

30. Correa, D.H.A.; Melo, P.S.; De Carvalho, C.A.A.; De Azevedo, M.B.M.; Duran, N.; Haun, M. Dehydrocrotonin and its $\beta$-cyclodextrin complex: Cytotoxicity in V79 fibroblasts and rat cultured hepatocytes. Eur. J. Pharm. 2005, 510, 17-24.

31. Sastry, K.V.H.; Moudgal, R .P.; Mohan, J.; Tyagi, J.S.; Rao, G.S. Spectrophotometric determination of serum nitrite and nitrate by copper-cadmium alloy. Anal. Biochem. 2002, 306, 79-82.

32. Hennig, C.; Rink, L.; Fagin, U.; Jabs, W.J.; Kirchner, H. The influence of naturally occurring heterophilic anti-immunoglobulin antibodies on direct measurement of serum proteins using sandwich ELISAs. J. Immunol. Methods 2000, 235, 71-80.

33. Eteshola, E.; Leckband, D. Development and characterization of an ELISA assay in PDMS microfluidic channels. Sensor. Actuat. B-Chem. 2001, 72, 129-133.

34. Nikulina, V.A.; Kizmi, E.A.; Massino, Y.S.; Segal, O.L.; Smirnova, M.B.; Avilov, V.V.; Saprigin, D.B.; Smotrov, S.P.; Tichtchenko, V.A.; Kolyaskina, G.I.; et al. Synergistic effects in antigen capture ELISA using three monoclonal antibodies directed at different epitopes of the same antigen. Clin. Chim. Acta 2000, 299, 25-44.

Sample Availability: Samples of the compounds $\mathbf{9 a - d , 1 0 a - c}$ and $\mathbf{1 1}$ are available from the authors.

(C) 2013 by the authors; licensee MDPI, Basel, Switzerland. This article is an open access article distributed under the terms and conditions of the Creative Commons Attribution license (http://creativecommons.org/licenses/by/3.0/). 